\title{
North Atlantic influence on 19th-20th century rainfall in the Dead Sea watershed, teleconnections with the Sahel, and implication for Holocene climate fluctuations
}

\author{
Yochanan Kushnir ${ }^{\mathrm{a}, *}$, Mordechai Stein ${ }^{\mathrm{a}, \mathrm{b}}$ \\ ${ }^{a}$ Lamont-Doherty Earth Observatory, The Earth Institute, Columbia University, 61 Route 9W, Palisades, NY 10964, USA \\ ${ }^{\mathrm{b}}$ Geological Survey of Israel, 30 Malkhe Israel Street, 95501 Jerusalem, Israel
}

\section{A R T I C L E I N F O}

\section{Article history:}

Received 14 February 2010

Received in revised form

3 August 2010

Accepted 9 September 2010

\begin{abstract}
A B S T R A C T
The importance of understanding processes that govern the hydroclimate of the Mediterranean Basin is highlighted by the projected significant drying of the region in response to the increase in greenhouse gas concentrations. Here we study the long-term hydroclimatic variability of the central Levant region, situated in the eastern boundary of the Basin, as reveled by instrumental observations and the Holocene record of Dead Sea level variations.

Observations of 19th and 20th century precipitation in the Dead Sea watershed region display a multidecadal, anti-phase relationship to North Atlantic (NAtl) sea surface temperature (SST) variability, such that when the NAtl is relatively cold, Jerusalem experiences higher than normal precipitation and vice versa. This association is underlined by a negative correlation to precipitation in the sub-Saharan Sahel and a positive correlation to precipitation in western North America, areas that are also affected by multidecadal NAtl SST variability.

These observations are consistent with a broad range of Holocene hydroclimatic fluctuations from the epochal, to the millennial and centennial time scales, as displayed by the Dead Sea lake level, by lake levels in the Sahel, and by direct and indirect proxy indicators of NAtl SSTs. On the epochal time scale, the gradual cooling of NAtl SSTs throughout the Holocene in response to precession-driven reduction of summer insolation is associated with previously well-studied wet-to-dry transition in the Sahel and with a general increase in Dead Sea lake levels from low stands after the Younger Dryas to higher stands in the mid- to late-Holocene. On the millennial and centennial time scales there is also evidence for an antiphase relationship between Holocene variations in the Dead Sea and Sahelian lake levels and with proxy indicators of NAtl SSTs. However the records are punctuated by abrupt lake-level drops, which appear to be in-phase and which occur during previously documented abrupt major cooling events in the Northern Hemisphere.

We propose that the mechanisms by which NAtl SSTs affect precipitation in the central Levant is related to the tendency for high (low) pressure anomalies to persist over the eastern North Atlantic/ Western Mediterranean region when the Basin is cold (warm). This, in turn, affects the likelihood of cold air outbreaks and cyclogenesis in the Eastern Mediterranean and, consequently, rainfall in the central Levant region. Depending on its phase, this natural mechanism can alleviate or exacerbate the anthropogenic impact on the regions' hydroclimatic future.
\end{abstract}

(c) 2010 Elsevier Ltd. All rights reserved.

\section{Introduction}

According to climate model projections the Earth subtropical regions are destined to become more arid in the future as atmospheric greenhouse gas concentrations increase (Held and Soden, 2006; Meehl et al., 2007; Seager et al., 2007b). Of these regions, the Mediterranean Basin stands out to be the most severely affected

\footnotetext{
* Corresponding author.

E-mail address: kushnir@ldeo.columbia.edu (M. Stein).
}

by this trend (Christensen et al., 2007). Here, many areas are already stressed by low precipitation amounts and a shortage of water and the projected future stands to further exacerbate these conditions (Iglesias et al., 2007; Mariotti et al., 2009). In light of these model-based projections it is important to better understand the mechanisms that govern the region's hydroclimatic variability. Particularly important are mechanisms that affect natural climate variations on decadal and longer time scales, which can interact to enhance or diminish the influence of increasing greenhouse gas concentrations. The present study seeks to address this goal by 
drawing on a comparison between the relatively short modern instrumental observations and Holocene paleoclimate proxies.

Climate model integrations have become quite useful in looking at forced and natural climate variability on a broad range of time scales, which are relevant to understanding near- and long-term climate change. However, the global models used for such studies have relatively low resolution and thus questionable reliability in geographically complex regions such as the Mediterranean. Highresolution and regional models are too costly to run for the long intervals needed to study multidecadal and longer time-scale variability. In such situations real-world evidence is important for building insight into processes affecting regional climate variability. Unfortunately, the instrumental record is too short for robust assessment of such variability. This is where paleoclimate proxies of the Holocene are invaluable, particularly when they are interpreted in terms of their regional and global linkages and in comparison with model output and the 19th-20th century instrumental record as exemplified by, e.g., Denton and Broecker (2008), Graham et al. (2007), and Seager et al. (2007a). This study follows the example of these studies to address the long-term variability of precipitation in the Eastern Mediterranean (EM), specifically within the Levant region (Fig. 1a), where a sufficiently wet "Mediterranean climate" borders on an arid desert and where hydroclimatic variability affected human development from the late Pleistocene and through Holocene (e.g., Migowski et al., 2006). Here climate models project a $20 \%$ decrease in the annual mean precipitation by the end of the 21st century (Fig. 2) with a high degree of inter-model agreement.

At the heart of the Levant region lies the Dead Sea, a unique paleo-indicator of hydrological changes (cf. Stein, 2001). The Dead
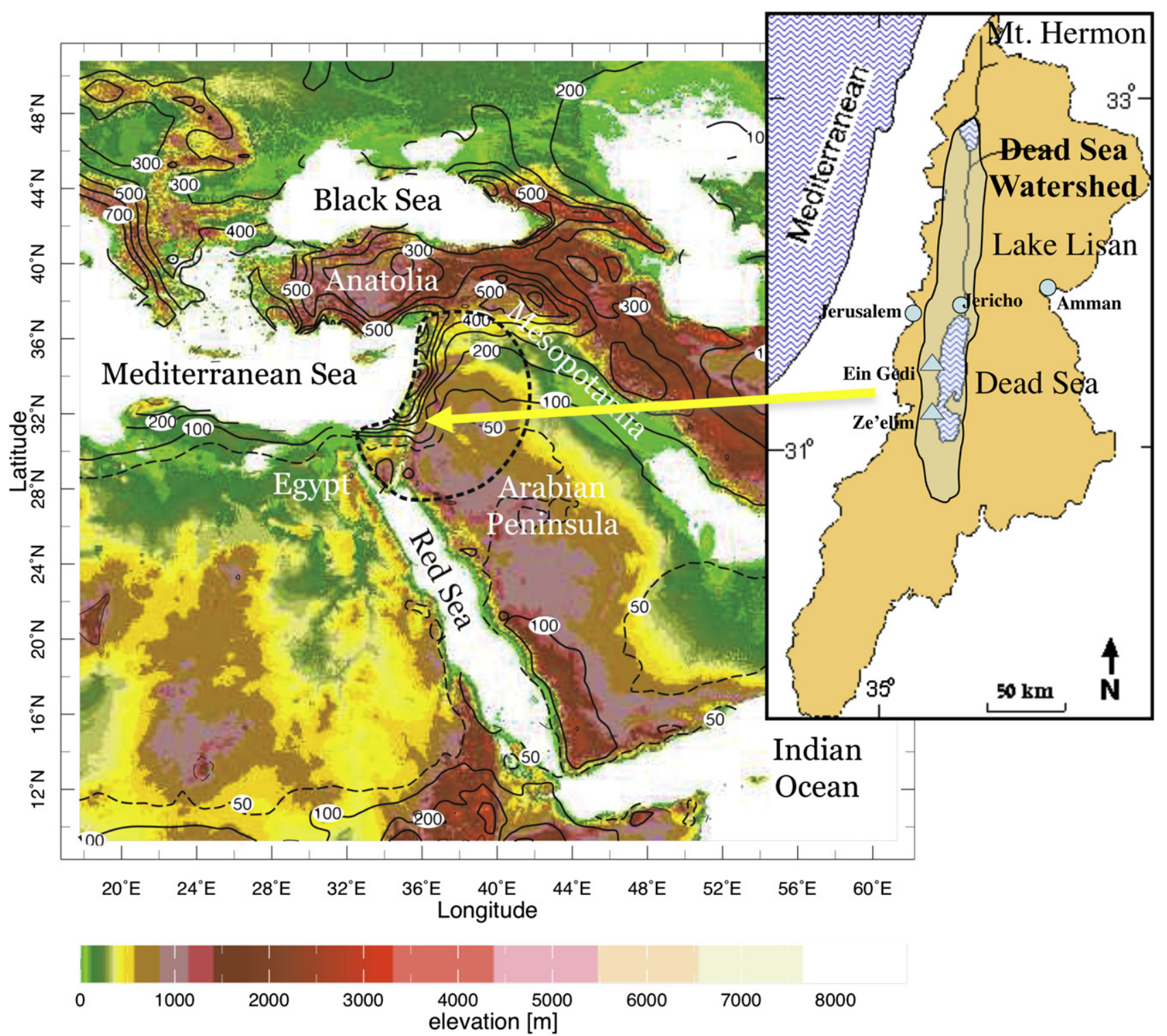

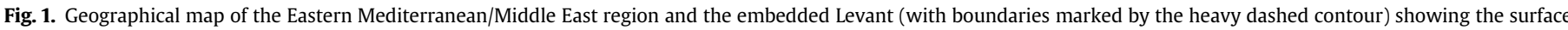

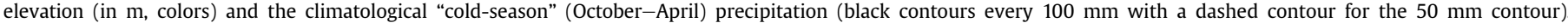

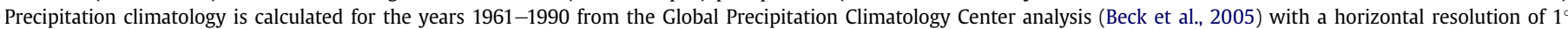

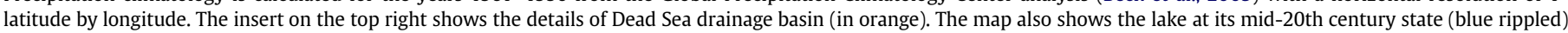

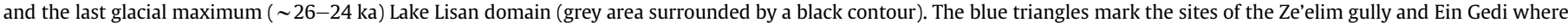
sedimentary sections of the Holocene Dead Sea were studied by Bookman (Ken-Tor) et al. (2004) and Migowski et al. (2006). 


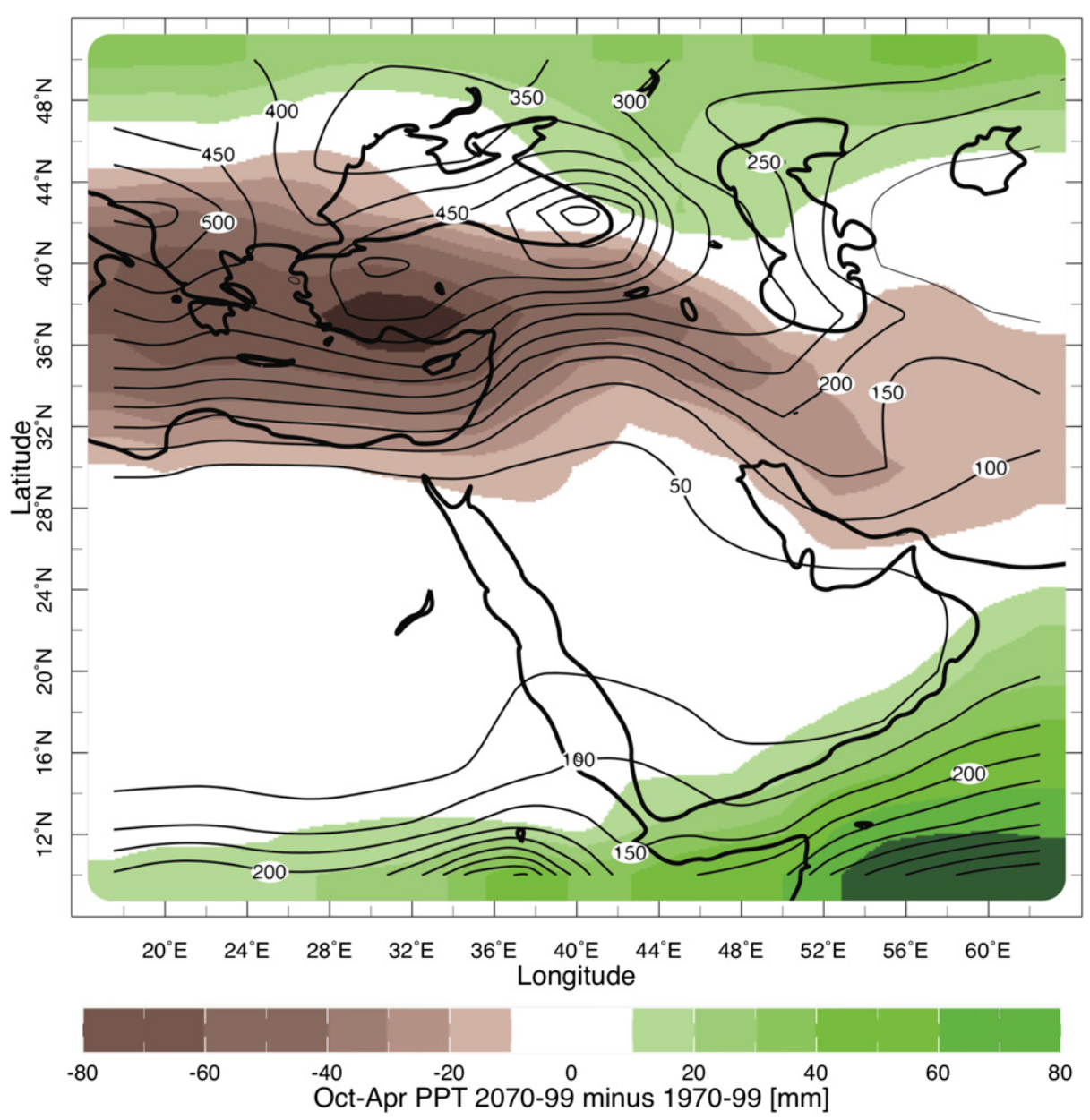

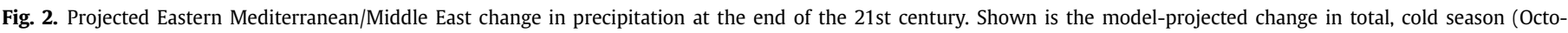

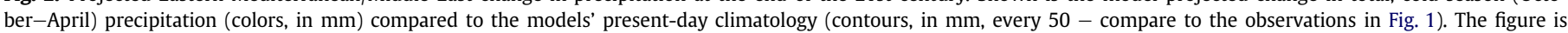

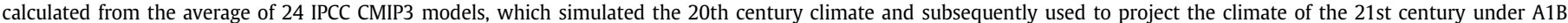
emission scenario (see IPCC, 2007).

Sea is a terminal lake, which displayed a large range of wellrecorded and dated lake level variations (Bookman (Ken-Tor) et al., 2004; Migowski et al., 2006; Waldmann et al., 2007; Stein et al., 2010). The Dead Sea is fed by a well-defined watershed (Fig. 1b), over which rainfall variations are quite coherent (Enzel et al., 2003 and see Section 3). This resource provides a look into the deep geological past as far as the last glacial interval and throughout the Holocene (e.g., Neev and Emery, 1995; Stein, 2001).

Because of the diverse data sources and broad range of time scales emphasized in this paper, we defer further discussion of the background for our investigation to the following chapters. The plan of this paper is as follows: Section 2 reviews briefly the use of the Dead Sea level (DSL) as a paleo-indicator of regional hydroclimatic variability. Section 3 addresses the multidecadal variability of precipitation in the lake's drainage basin as displayed by the Jerusalem instrumental record of the 19th and 20th century and a half and put it in a global context, particularly its link to the multidecadal variability of North Atlantic (NAtl) sea surface temperatures (SSTs). We argue that the broader, Northern Hemisphere pattern of precipitation variability, linked with the Jerusalem record, suggests an important role for the Atlantic in Levant climate variability, specifically the variations of rainfall in the Dead Sea watershed region. In Section 4 we bring forward the Holocene proxy record of DSL variations during the last $\sim 10,000$ years. Here too we discuss the variability in a global context by examining and comparing the DSL record with proxy evidence of hydroclimate variability in sub-Saharan Africa and North America, which together support the claim made on the basis of the much shorter instrumental record. The discussion in Section 4 is divided to a broad examination of epochal changes during the entire Holocene and of its millennial to centennial variability. A dynamical mechanism for the regional and associated, more global variability is proposed in Section 5. We conclude with a summary and brief discussion of the implications of our study for the regions' hydroclimatic future.

\section{The Dead Sea as a paleo-hydroclimatic gauge of the Levant}

During the last glacial - Holocene climatic cycles, the Levant region underwent significant changes in the amount and, possibly, pattern of precipitation over a wide range of time scales, from decadal to millennial. These changes were reflected in the regional hydrological systems, particularly in the supply of riverine runoff and groundwater to lakes that occupied the tectonic depressions along the Dead Sea transform, e.g., the mid-late Pleistocene lakes Amora and Samra, the late Pleistocene Lake Lisan, the Holocene Dead Sea and the Sea of Galilee (Fig. 1; Neev and Emery, 1967; Begin et al., 1974; Stein, 2001; Haase-Schramm et al., 2004; Hazan et al., 2005; Waldmann et al., 2007, 2009; Torfstein et al., 2009; Stein et al., 2010). The lakes that have occupied the Dead Sea basin are 
considered terminal lakes, which levels have been sensitive to the amount of incoming water and evaporation. They thus provide a record of hydroclimatic variability in the Dead Sea watershed region, a record that extends over the last $70 \mathrm{ka}$ (Bartov et al., 2003; Enzel et al., 2003). That said, several factors are combined in the shaping of the composition and limnological configuration of the lakes (e.g., layered or overturned lake, salinity and evaporation, hydrological conditions in the watershed region, see Stein et al., 1997) and we do not expect the lake response to regional climate and hydrology to be immediate or linear.

The Holocene Dead Sea (Fig. 1b and see Neev and Emery, 1967) consists of two basins: a deep northern basing ( $2300 \mathrm{~m}$ deep), occupying about two thirds of the lake and a very shallow southern basin (which is currently essentially dry). The basins are separated by a sill at a level of $\sim 402-403 \mathrm{~m}$ bmsl. As seen in Fig. 3, the Holocene Dead Sea fluctuated between levels of $\sim 430$ and $370 \mathrm{~m}$ below mean sea level (bmsl) and rose or declined beneath the sill. Dead Sea levels are a function of freshwater influx to the lake, which itself is a function of precipitation over the larger watershed regions particularly in the northern part. Opposing the inflow is the evaporation of water from the lake surface. The lake also receives a small but not insignificant net inflow from underground.

The response of lake levels to freshwater influx, particularly that associated with precipitation over the watershed basin, was addressed in some detail by Enzel et al. (2003). They noted the importance of the sill as introducing a discontinuity in the lake response to freshwater influx. Specifically, flooding the southern basin leads to an abrupt increase in the total lake evaporative flux, which buffers further increases in lake levels. In contrast, when lake levels drop below the sill, the surface level becomes more sensitive to changes in freshwater flux as the lake is confined to the northern basin (see also Bookman (Ken-Tor) et al., 2004). Additional complexities in lake level response to freshwater influx are associated with changes in the surface area as the level changes (Abu Ghazleh et al., 2009) and the dependence of the rate of evaporation to its surface salinity (Stanhill, 1994; Asmar and Ergenzinger,
1999). In particular, evaporation estimates provided by Stanhill (1994) support the notion that in this hypersaline lake evaporation can buffer lake level drops, as the volume of the lake decreases and the lake becomes saltier.

Despite these complexities, Enzel et al. (2003) argued for a relatively simple relationship between lake level and regional precipitation using the instrumental precipitation record at Jerusalem and the measured lake levels recorded between 1870 and 1964 , before human intervention to the flow of the Jordan River and when lake levels stayed above the sill. They found that during that interval, the lake levels display a multi-year rise when the annual precipitation amounts in Jerusalem are distributed around a mean of $648 \mathrm{~mm}$ with standard deviation of about $122 \mathrm{~mm}$ and a multiyear decline when the annual precipitation amounts drop to a mean of $445 \mathrm{~mm}$, with a standard deviation of $117 \mathrm{~mm}$. From their data, one could conclude that the rate of decline in lake level in the time interval of $1930-1960$ is $8-10 \mathrm{~cm} \mathrm{y}^{-1}$ consistent with the overall low annual precipitation amounts during that period (average of $568 \mathrm{~mm}$ compare to the entire record average of $607 \mathrm{~mm}$ ). In particular, between 1930 and 1945, DSL dropped by $2 \mathrm{~m}$, yielding a rate of decline of $14 \mathrm{~cm} \mathrm{y}^{-1}$. This rapid decline came in the wake of the 10-year precipitation minimum of the entire instrumental record, between 1925 and 1934, averaging $390 \mathrm{~mm} \mathrm{y}^{-1}$.

\section{Regional precipitation during the instrumental record}

The Levant rainy season spans the months of October to April with most of the rainfall confined to the core winter months of December, January, and February. During the rainy season, coldcore, upper-level, low-pressure troughs migrate from west to east over southern Europe and the Mediterranean (Ziv et al., 2006; Trigo, 2006). These systems drive cold and relatively dry air masses from Europe over the mountain ranges that circle the EM Basin to the north to encounter the relatively warm sea surface. This process leads to the formation of surface low-pressure systems

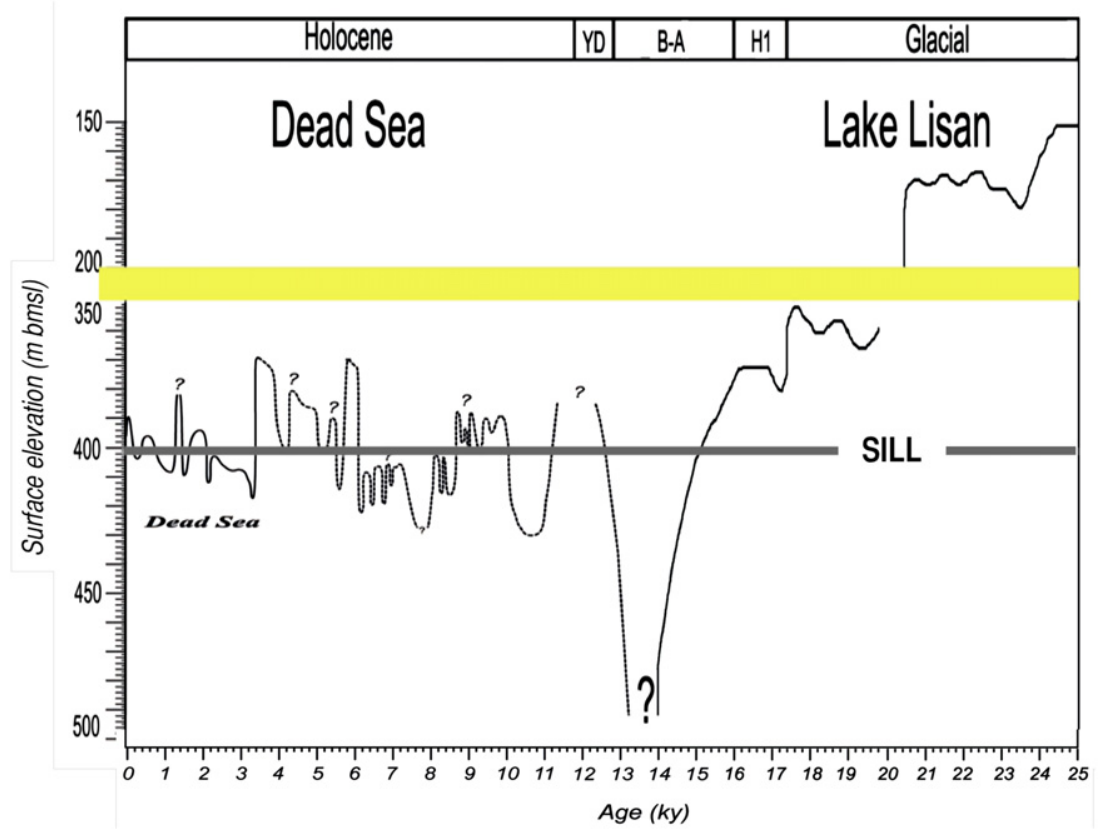

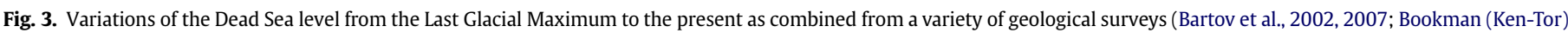

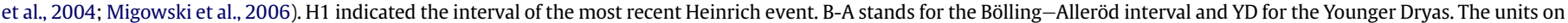

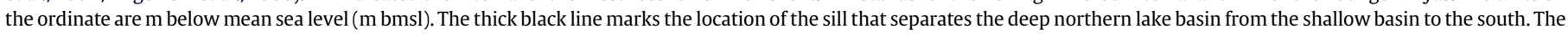
thick yellow line indicates a break in the depth scale. (For interpretation of the references to color in this figure legend, the reader is referred to the web version of this article). 

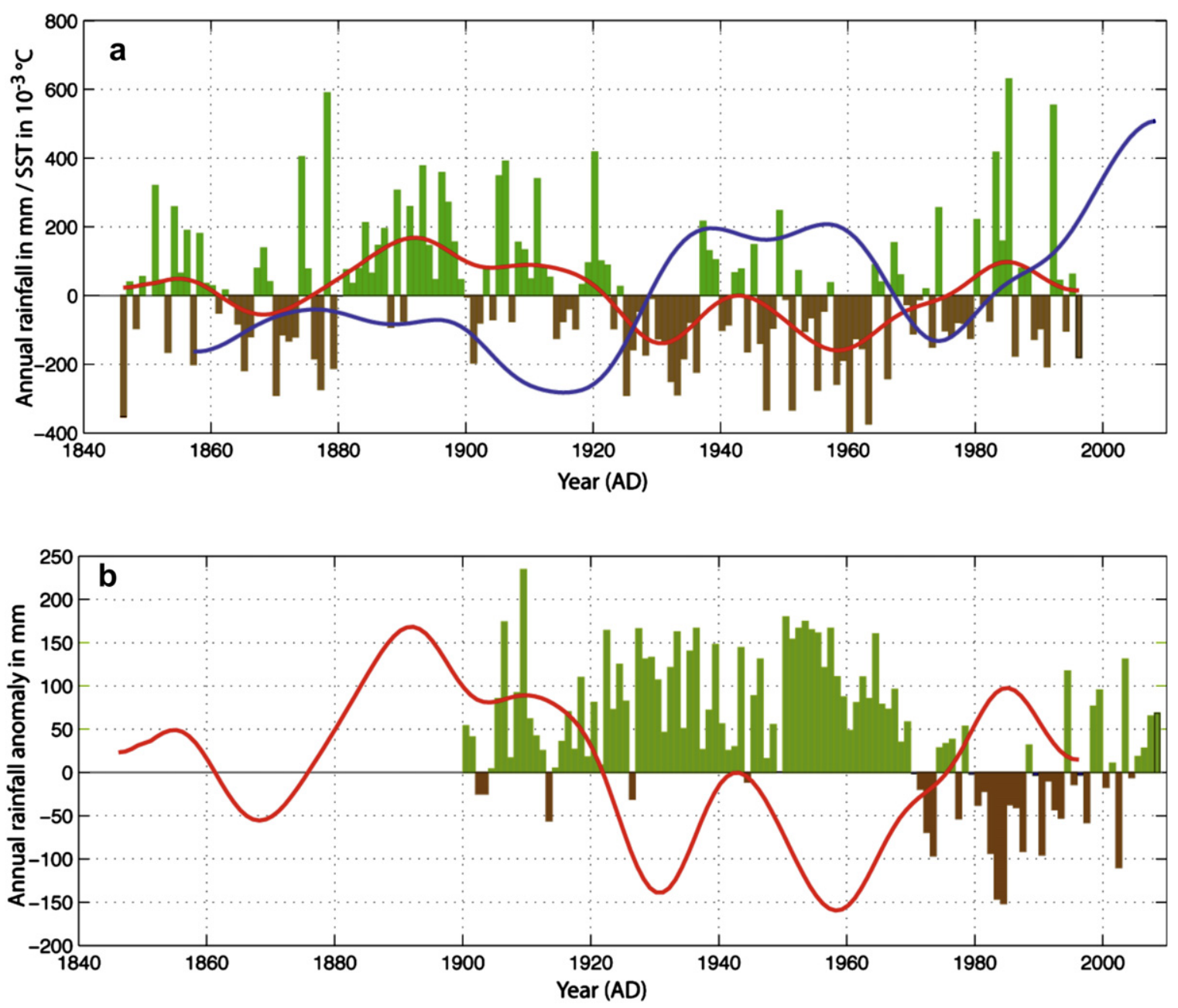

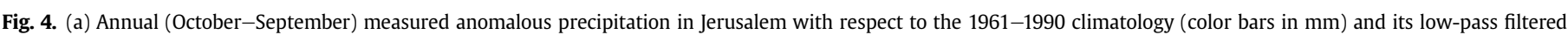

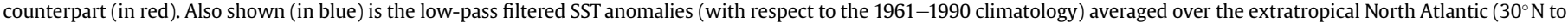

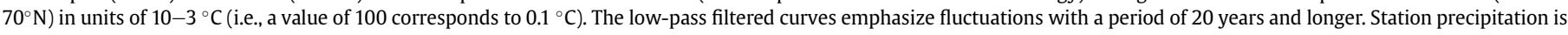

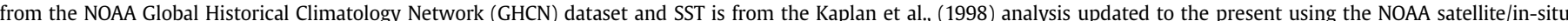

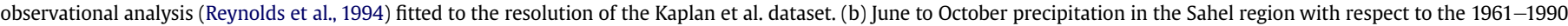

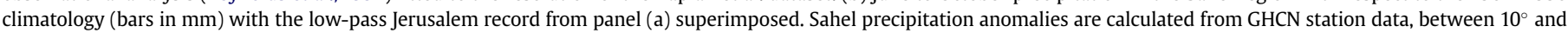
$20^{\circ} \mathrm{N}$, relative to the 1961-1990 climatology. (For interpretation of the references to color in this figure legend, the reader is referred to the web version of this article).

(cyclones), which lift the now moistened marine air to produce clouds and precipitation. Of particular importance for the Levant region (and the Dead Sea watershed area) are the cyclones that tend to form (or re-form) in the EM, known as Cyprus Lows (cf. Enzel et al., 2003; Ziv et al., 2006). The Levant's topographic features in relation to the prevailing winds and the shape of its coastline govern the distribution of precipitation over the adjacent land areas (Ziv et al., 2006), enriching the Levant coastal plains and mountain ridges to the east, thus feeding the Jordan River, its tributaries and subsequently the Dead Sea. During the other half of the year (May to September) the EM and the Levant are dry due to the strong regional subsidence induced by the remote influence of the Indian summer monsoon system (Rodwell and Hoskins, 1996; Ziv et al., 2004).

Seeking an explanation for the temporal variability of seasonal rainfall in the central Levant, scientists looked for relationships to seasonal changes in the atmospheric circulation (e.g., Ziv et al., 2006 and references therein). The dominant regional teleconnection pattern that is associated with interannual precipitation variability in the Levant is the East Atlantic/Western Russia (EA/ WR) pattern, which describes a seesaw in pressure between Western Europe and the Caspian Sea (Wallace and Gutzler, 1981;
Barnston and Livezey, 1987; Krichak et al., 2000; Ziv et al., 2006). During a wet winter in the Levant the pattern exhibits, expectedly, an anomalous high-pressure center over the eastern NAtl, just south of the British Isles and an anomalous low-pressure center over the EM, extending as a trough from the Caspian Sea area and vice versa (Enzel et al., 2003; Ziv et al., 2006). If this configuration exists, on average, throughout or during parts of the rainy season, precipitation is blocked from occurring in the western part of the Mediterranean Basin and upper-level, low-pressure systems with their cold air intrusions and consequential rainfall, are steered to the EM.

The role of more global climate phenomena in Levant precipitation variability is less clear. In previous studies (see Ziv et al., 2006 and references therein) connections were sought to dominant phenomena associated with interannual to decadal global climate variations, in particular, the El Niño/Southern Oscillation (ENSO) phenomenon, which influence on the hydrological cycle extends worldwide (Seager et al., 2005) and the NAtl Oscillation (NAO) that influences hydrological variability in and around the Atlantic Basin (Hurrell et al., 2003). The NAO is associated with coherent latitudinal fluctuations in the NAtl wintertime eddy-driven jet stream. Connected with that are swings in the location of the Atlantic 


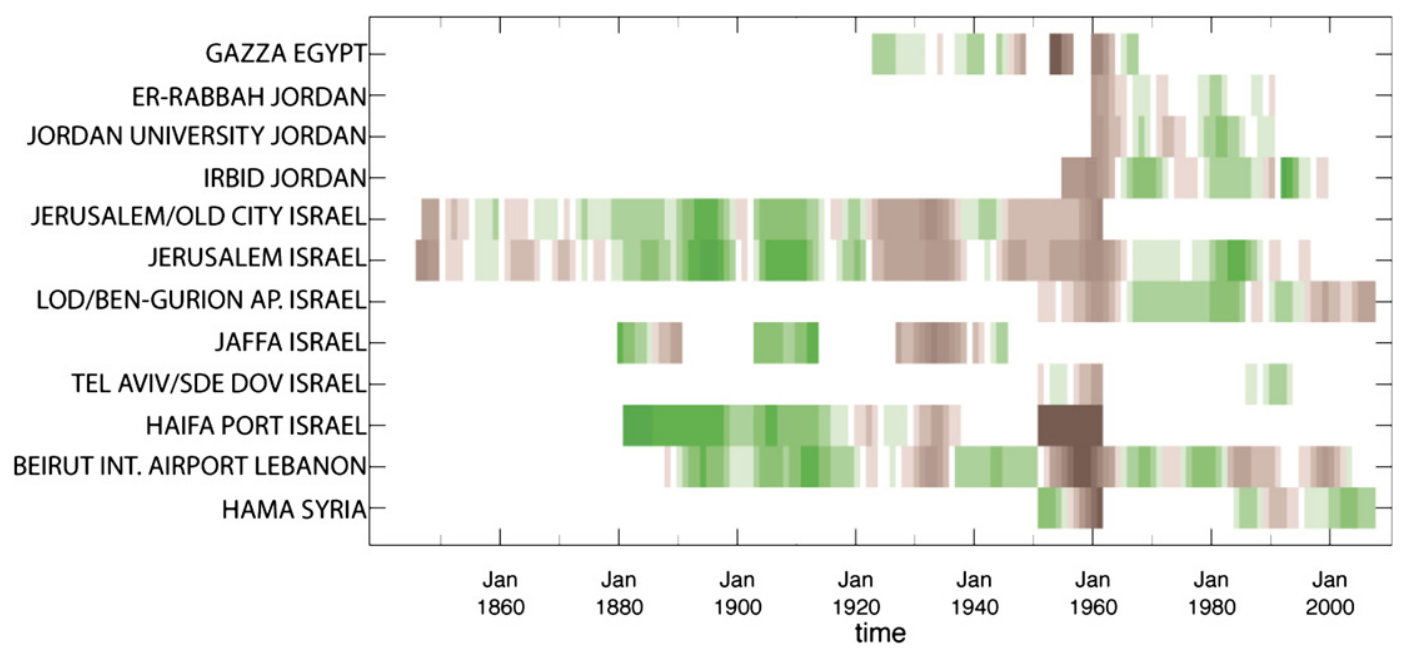

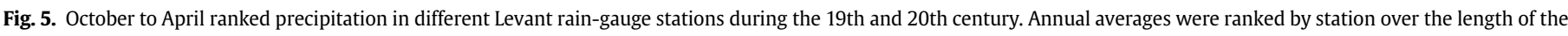

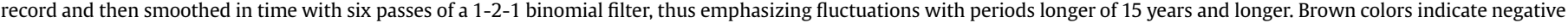
anomalies (dry years) and green ones are positive (wet years).

winter storm track between a northern and a southern path, depending on the NAO phase (Hurrell et al., 2003; Lee and Kim, 2003). The downstream effect of this Atlantic-centric phenomenon "spills" into the northern Mediterranean countries all the way to the EM: a negative NAO phase associates with larger than normal rainfall from Spain to Turkey, and a positive NAO phase leads to lower than normal precipitation there (Cullen and deMenocal, 2000; Marshall et al., 2001). However, in the Levant and along the eastern part of the North African coast the influence of the NAO on precipitation is weak and possibly in opposite phase (Cullen and deMenocal, 2000; Enzel et al., 2003).

A link between Levant precipitation (in the Dead Sea watershed) and ENSO is discussed in Price et al. (1998). They found a significant positive correlation between SST in the eastern equatorial Pacific and wintertime (December-February) precipitation in northern Israel (specifically, the village of Kfar Giladi in the Mt Hermon foothills). What is puzzling about this relationship is that Price et al. (1998) found it only in post 1970 data and not before that. Seager et al. (2005), using a relatively short, recent record of a global precipitation analysis based on merged rain-gauge data and satellite observations, showed that the ENSO-Levant correlation can be viewed as a part of the largely zonally symmetric response of the global hydrological cycle to interannual, eastern equatorial Pacific SST variability. Mariotti et al. $(2002,2005)$ found a clear ENSO linkage to Mediterranean (Levant included) precipitation but only in the relatively marginal fall season (September-November). Thus one cannot rule out an overall weak influence of ENSO on the Levant wet season (October-April).

Here we present evidence for a different association, operating on multidecadal to millennial time scales, which controls precipitation variability in the central Levant and affects the Dead Sea watershed region. Specifically, we propose that the decadal and longer time-scale hydroclimatic variations of this region are affected by the multi-year variability of NAtl SSTs. We will later argue that this influence works through the ability of SST variations in the Atlantic to influence the phase of the EA/WR teleconnection pattern, depending on their sign.

The most direct evidence for this Atlantic-Levant relationship emerges from the examination of the observed Jerusalem precipitation record and comparing it to the observed, multidecadal variations of NAtl SST presented in Fig. 4a. This figure shows the annual, hydrological-year (October-September) precipitation anomaly in Jerusalem between 1847 and 1996 and its low-pass filtered version as well as the low-pass filtered anomalous SSTs averaged in the NAtl Basin. Two low-pass time series suggest an anti-phase relationship (more below). However, the records presented in Fig. 4a are short compared to the associated time scales and further evidence is necessary to corroborate the proposed relationship. The search for such evidence in the proxy data is the objective of this study.

The phenomenon of Atlantic Multidecadal SST variability, hereafter Atlantic Multidecadal Variability $\left(\mathrm{AMV}^{1}\right)$, has received considerable attention in the last two decades or so (e.g., Folland et al., 1986; Kushnir, 1994; Schlesinger and Ramankutty, 1994; Kerr, 2000; Gray et al., 2004; Knight et al., 2006; Ting et al., 2009). The observations suggest that the AMV displays a basinwide coherence and maintains high season-to-season (i.e., winterto-summer), and year-to-year correlation (Kushnir, 1994).

As argued by Enzel et al. (2003), year-to-year and longer-term variations in Jerusalem precipitation are representative of precipitation variability in the core of the Levant including the Dead Sea watershed region. The agreement between precipitation in Jerusalem and in other cities in the core of the Levant stands out, in particular, on multidecadal and longer time scales (see Fig. 5). This regional agreement indicates that the climate of the central Levant was relatively wet between 1880 and 1925 and dry between 1925 and 1970, with a short break around 1940. After 1970 the balance overall was neutral with relatively short, wet and dry intervals, in succession. Figs. 4a and 5 thus indicates that when SSTs in the NAtl Ocean were below normal, between about 1880 and 1930, precipitation in the Levant often exceeded normal but when NAtl SST rose above normal, between about 1930 and the mid-1960s, precipitation was mostly below normal. Partial return to above normal precipitation accompanied two cool decades in NAtl in the late 20th century. The Jerusalem record and most of the other station records used in Fig. 5 have not been updated yet to indicate recent precipitation trends associated with the rather abrupt warming of the NAtl after the mid-1990s.

\footnotetext{
${ }^{1}$ Most sources refer to this phenomenon as the Atlantic Multidecadal Oscillation (AMO). We prefer to refer to it as "variability" rather than "oscillation" to emphasize its irregular temporal behavior exhibited in models and proxy data such as Gray et al. (2004).
} 
Additional instrumental support for the role of the Atlantic in Levant precipitation comes from examining the relationship between the Jerusalem record and precipitation in the other land areas. In particular, the anti-phase relationship between precipitation in Jerusalem and in the Sub-Saharan Sahel region, the semi-arid region, which lies at the northern edge of Africa's wet tropical belt, during its wet seasons (June-October, Fig. $4 \mathrm{~b}^{2}$ ). Many past studies indicated that the AMV plays a critical role in longterm variations of Sahel precipitation during the African summer monsoon season, such that when NAtl SSTs are warmer than normal (particularly with respect to their South Atlantic counterparts) the African summer monsoon rains spread further northward leading to a wetter than normal Sahel, and vice versa (see recent review by Giannini et al., 2008). When it comes to the relationship between Sahel and Levant precipitation, we do not expect high-frequency, year-to-year fluctuations to be related, because of the different climatic processes governing them and the seasonal contrast (i.e., boreal winter for Jerusalem and boreal summer for the Sahel). However, on the long, multidecadal timescale the year-round persistence of NAtl SST variability links the two regions' hydrological cycle anomalies and explains the striking anti-phase relationship exhibited in Fig. 4. We will later show that the Holocene proxy record is consistent with this assertion and thus provide further evidence for the role of NAtl Ocean SSTs in Levant precipitation.

The broad pattern of the relationship between annual precipitation variability in Jerusalem and in the surrounding Northern Hemisphere land areas is revealed in Fig. 6a. The figure, which is derived from 1921 to 1996 gridded rain-gauge data (from GPCC, Beck et al., 2005), displays significant correlation values both locally and in remote regions. In the Levant and over Northern Egypt significant positive values may be due, in part, to the analysis interpolation but during data rich periods the interpolation effect should be small. The significant negative correlations are found in sub-Saharan Africa as well as in the Iberian Peninsula and in Morocco, and positive correlations exist in Scandinavia and the northern tip of the British Isles. This relationship indicates that large-scale climate mechanisms are in control. Again the evidence points at the NAtl.

In Fig. 6a significant positive correlation values are also found in North America, in the middle of the continent and in the West. Additional support for this remote association is seen in Fig. 6b, in which the entire Jerusalem record (1847-1996) was correlated with the North American Drought Atlas annual PDSI values (NADA, Cook et al., 2004), which reconstructs the hydroclimate history for the last $\sim 2000$ years over North America and Mexico from precipitation sensitive tree-ring chronologies (see also Cook et al., 2007). The American West (and Northern Mexico) are recognized now as regions that are affected by NAtl SST fluctuations such that when the latter are warmer than normal, hydrological-year precipitation in the American West is lower than normal and vice versa - just as we suggest is the case with the Levant (Enfield et al., 2001; McCabe et al., 2004; Sutton and Hodson, 2007; Kushnir et al., in press).

To summarize: the observational evidence presented above suggests that AMV provides the connecting link between central Levant, Sahel and North America precipitation variability on

\footnotetext{
2 Sahel is defined here as the land area between $10^{\circ}$ and $20^{\circ} \mathrm{N}$ and between $20^{\circ} \mathrm{W}$ and $40^{\circ} \mathrm{E}$. The number of Sahel stations reporting is between 5 and 20 until $\sim 1920$ and reaches 35-40 after that. Note that the Sahel precipitation anomalies (in Fig. 4b) are calculated with respect to the 1961-1990 climatology (as are the Jerusalem anomalies). This climatology is tilted towards the low-rainfall years and thus the negative anomalies appear less accentuated than in other representation of this record.
}

multidecadal time scales. When the NAtl is colder than normal we tend to find higher than normal precipitation in the central Levant and North America (over the western half of the continent) and lower than normal precipitation in the Sahel Africa. Conversely, when the NAtl is warmer than normal we find lower than normal precipitation in the central Levant and North America and higher than normal precipitation in the Sahel. It is possible that SST fluctuations in other ocean basins (e.g., the tropical Pacific and Indian Ocean) are participating in orchestrating the relationship seen in Fig. 6 (McCabe and Palecki, 2006). However, as we continue to demonstrate below, the NAtl link is the centerpiece of this relationship and provides important insight into the source of longterm hydroclimate variability in the Levant during the Holocene.

\section{Global hydrological connections with the Holocene Dead Sea record}

\subsection{Secular change during the Holocene epoch}

The Holocene Dead Sea evolved from the last glacial Lake Lisan, which was a large water body extending from the Sea of Galilee to northern Arava valley with elevations about $200 \mathrm{~m}$ above those of the Holocene Dead Sea (Bartov et al., 2003; Bookman (Ken-Tor) et al., 2007). As indicated in Section 2, Lake Lisan reached its highest elevations of $\sim 160-200 \mathrm{~m}$ bmsl during Marine Isotope Stage 2 (MIS2) (Fig. 3 and Bartov et al., 2003) and gradually retreated during the late-glacial period, between $\sim 24$ and $\sim 15$ ka cal BP (Stein et al., 2010). During the Bölling-Alleröd period, between 14 and $13 \mathrm{ka}$ cal BP the lake level dipped to its lowest measured level (possibly below $450 \mathrm{~m} \mathrm{bmsl}$ ), regaining above-sill levels during the Younger Dryas, around $12 \mathrm{ka}$ BP and dipping again below the sill at the onset of the Holocene, at $11 \mathrm{ka}$ BP (Stein et al., 2010 and see Fig. 3). At that time the sub-Saharan Sahel region began a transformation from an arid desert into a relatively wet region, marking the transition to the African Humid Period (AHP, deMenocal et al., 2000; Gasse and Roberts, 2005 and see Fig. 7).

The AHP followed the march of the precession cycle depicted in the boreal summer insolation curve shown in Fig. 7a, Boreal summer insolation intensity governs the activity of the West African monsoon (and other monsoon systems as well) on geological time scales (Kutzbach, 1981; Kutzbach and Liu, 1997; deMenocal et al., 2000; Liu et al., 2004; Gasse and Roberts, 2005). The early- to mid-Holocene Northern Hemisphere low-latitude summer insolation maximum arrived at its peak at 10-11 ka BP followed by a gradual decline towards average values at $\sim 5.5 \mathrm{ka}$ cal BP, when the AHP terminated. The impact of the insolation changes reached beyond the tropics into the NAtl as evident from alkenone paleothermometry, which shows that at the peak of insolation, the NAtl was about $3{ }^{\circ} \mathrm{C}$ warmer than at present, particularly over the eastern part of the Basin (Kim et al., 2007). With the decrease in summer insolation, NAtl SST gradually cooled to the levels observed today.

In the Dead Sea basin the early Holocene interval of $\sim 11-6$ ka BP began by a significant, post YD (between 11-10 ka BP) drop in the lake level and deposition of halite sequences. The overall regional aridity during the Holocene first four millennia stands in contrast to the wetness of the Sahel region during that time interval (Fig. 7). On average, lake levels were low during these five millennia, particularly so between $\sim 8.6$ and 6.2 ka BP where levels stood significantly below the sill, reflecting extreme arid conditions in the watershed region (Fig. 3, and Migowski et al., 2006; Stein et al., 2010). The earlier interval, between 10 and 8.6 ka BP, displays rapid fluctuations with intermittent above-sill levels. The climate of this interval was still marked by ice sheet remnants in the high latitudes of eastern North America and 

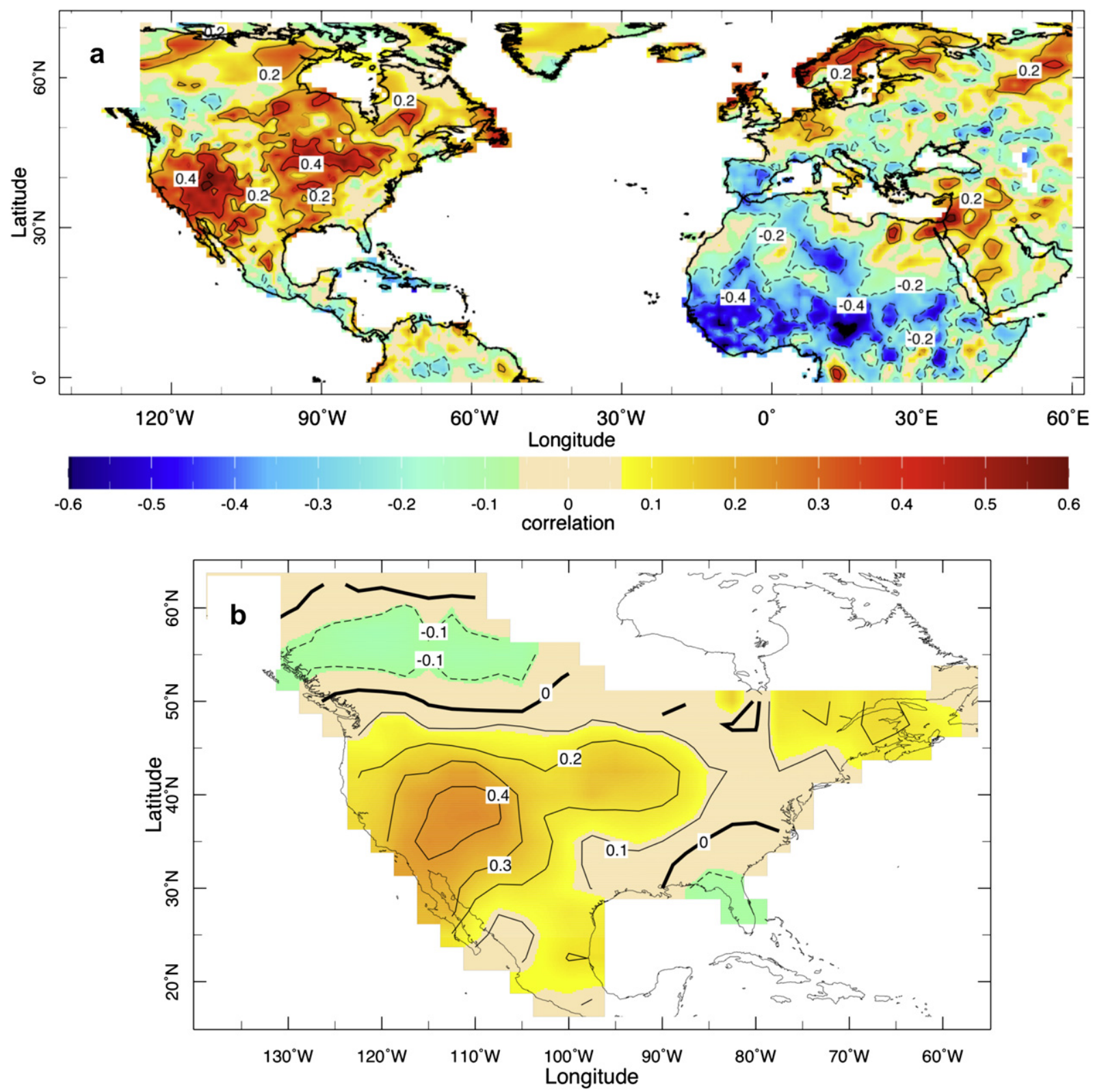

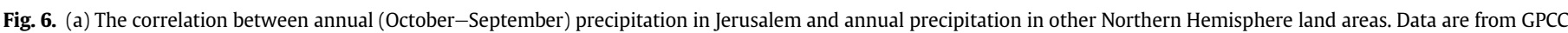

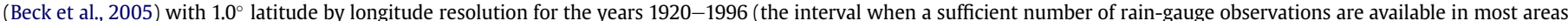

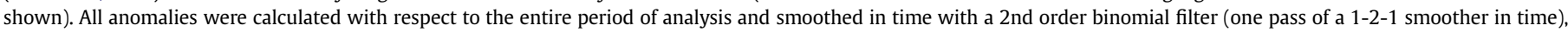

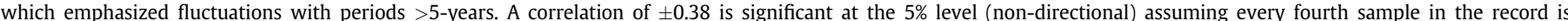

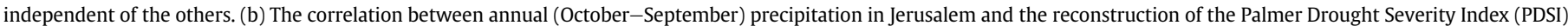

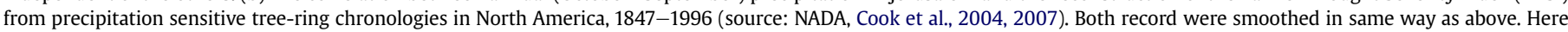
a correlation of \pm 0.28 is significant at the $5 \%$ level.

Western Europe and sea levels were still quite low, marking a transition of the climate system from glacial to interglacial conditions, and rendering the interpretation of the regional hydroclimate more difficult.

During the early Holocene ( 10-6 ka BP), when the DSL stood low on average and the African Monsoon was at its peak activity, other EM proxies also exhibit anomalous conditions from which conflicting interpretation emerged regarding the region's hydroclimatic conditions. In the Aegean Sea and in the EM west and south of Cyprus, stable isotope time series, derived from foraminifera in sediment cores, suggest that the sea surface was flooded by freshwater that originated in southern latitudes, as expressed by low $\delta^{18} \mathrm{O}$ values of the seawater (Kolodny et al., 2005; Marino et al., 2009; Almogi-Labin et al., 2009). This time interval is referred to as the time of the Mediterranean Sapropel S1, identified by the dark-colored sediment layer, rich in organic matter in the EM cores (Rossignol-Strick et al., 1982; Rohling and Hilgen, 1991; Rohling, 1994; Rossignol-Strick, 1999; Casford et al., 2003). Ideas regarding the source of freshwater vary, with some papers proposing a local source (i.e., enhanced precipitation in the EM region) and consistently referring to the interval between $\sim 10$ and $\sim 6 \mathrm{ka}$ BP as the "humid early Holocene" period (e.g., BarMatthews et al., 2000; Arz et al., 2003), an interpretation which stands in contrast to the overall low DSLs. However, most of the evidence, points at the Nile River floods as the major source of freshwater to the EM, arguing that at that time, the river was fed 


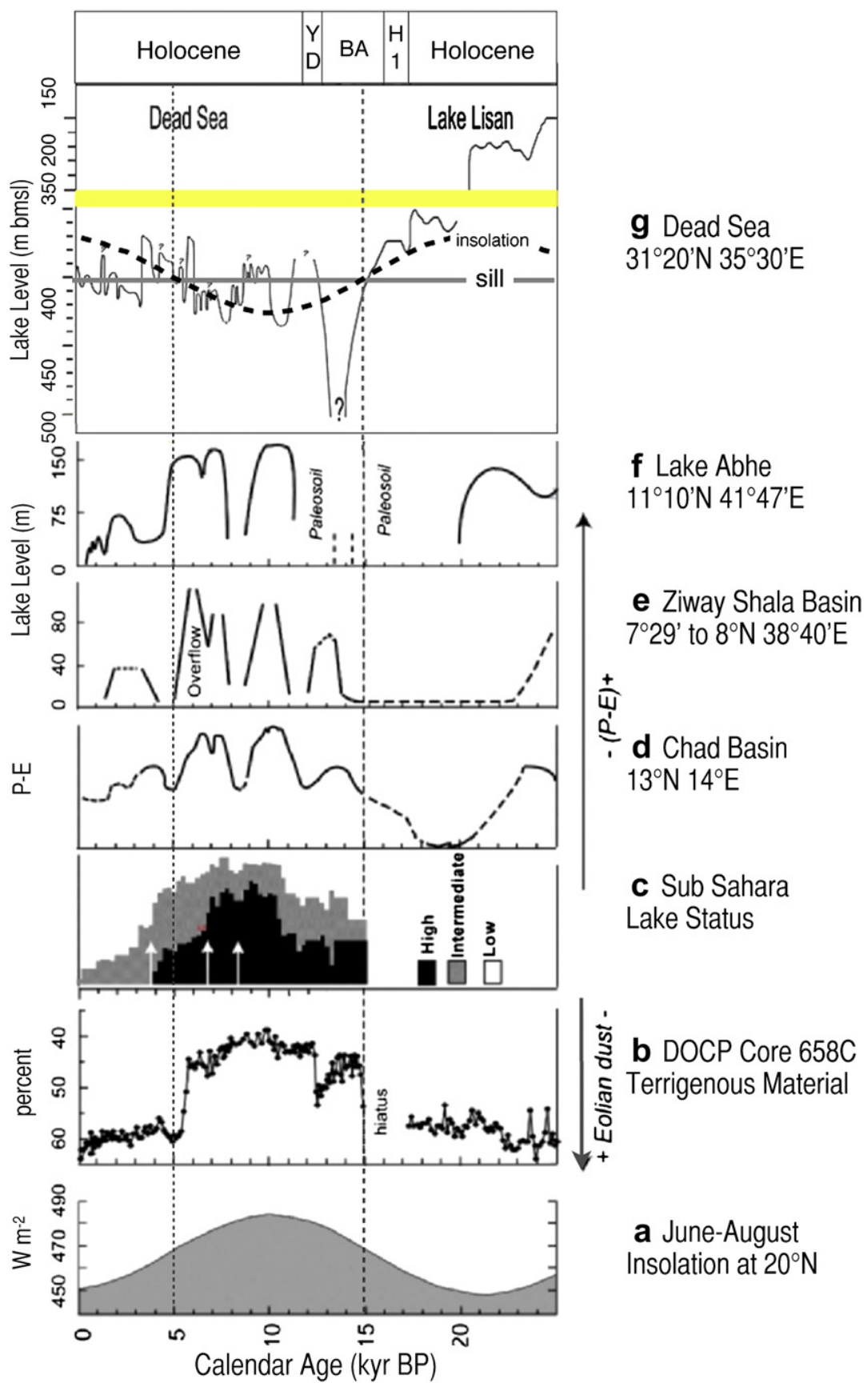

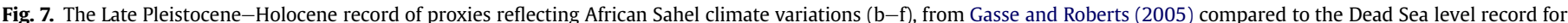

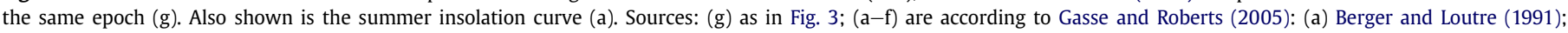

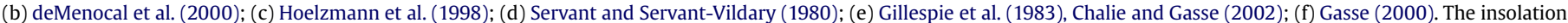
curve is reflected along the horizontal axis and plotted on top of the Dead Sea level record to emphasize the epochal changes.

by the vigorous, early Holocene, African monsoon rainfall (Adamson et al., 1980; Rossignol-Strick et al., 1982; Rohling, 1994; Rossignol-Strick, 1999; Marino et al., 2009). This EM low $\delta^{18} \mathrm{O}$ signal was also recorded in Dead Sea aragonite deposits and the Soreq Cave speleothem record, located west of the Dead Sea in the Judea foothills (Kolodny et al., 2005; Almogi-Labin et al., 2009 and references therein) and also matches the $\delta^{18} \mathrm{O}$ record from a speleothem taken from Jeita cave, near Beirut Lebanon (Verheyden et al., 2008). To be consistent with the low DSL stands of that era, the low $\delta^{18} \mathrm{O}$ values in the lake and cave deposits should be interpreted as reflecting the low $\delta^{18} \mathrm{O}$ in the water evaporated from the depleted EM source (i.e., the so called "source effect" Kolodny et al., 2005; Marino et al., 2009).

Around $6 \mathrm{ka}$ BP the DSL rose significantly to the elevation of $\sim 370 \mathrm{~m}$ bmsl (Fig. 3; and see Migowski et al., 2006; Bartov et al., 2007) and through several fluctuations remained at high-stand until $\sim 3.5 \mathrm{ka}$ BP. In The mid-Holocene ( $\sim 6 \mathrm{ka}$ ), dry-to-wet transition of the Dead Sea watershed region is in anti-phase to the concomitant drying of the Sahel where the AHP terminated (Fig. 7). Around $\sim 3.5 \mathrm{ka}$ cal BP the Dead Sea suffered an abrupt drop from which it recovered at $\sim 2 \mathrm{ka}$ cal BP (see discussion below regarding higher frequency oscillations) and continued with small 


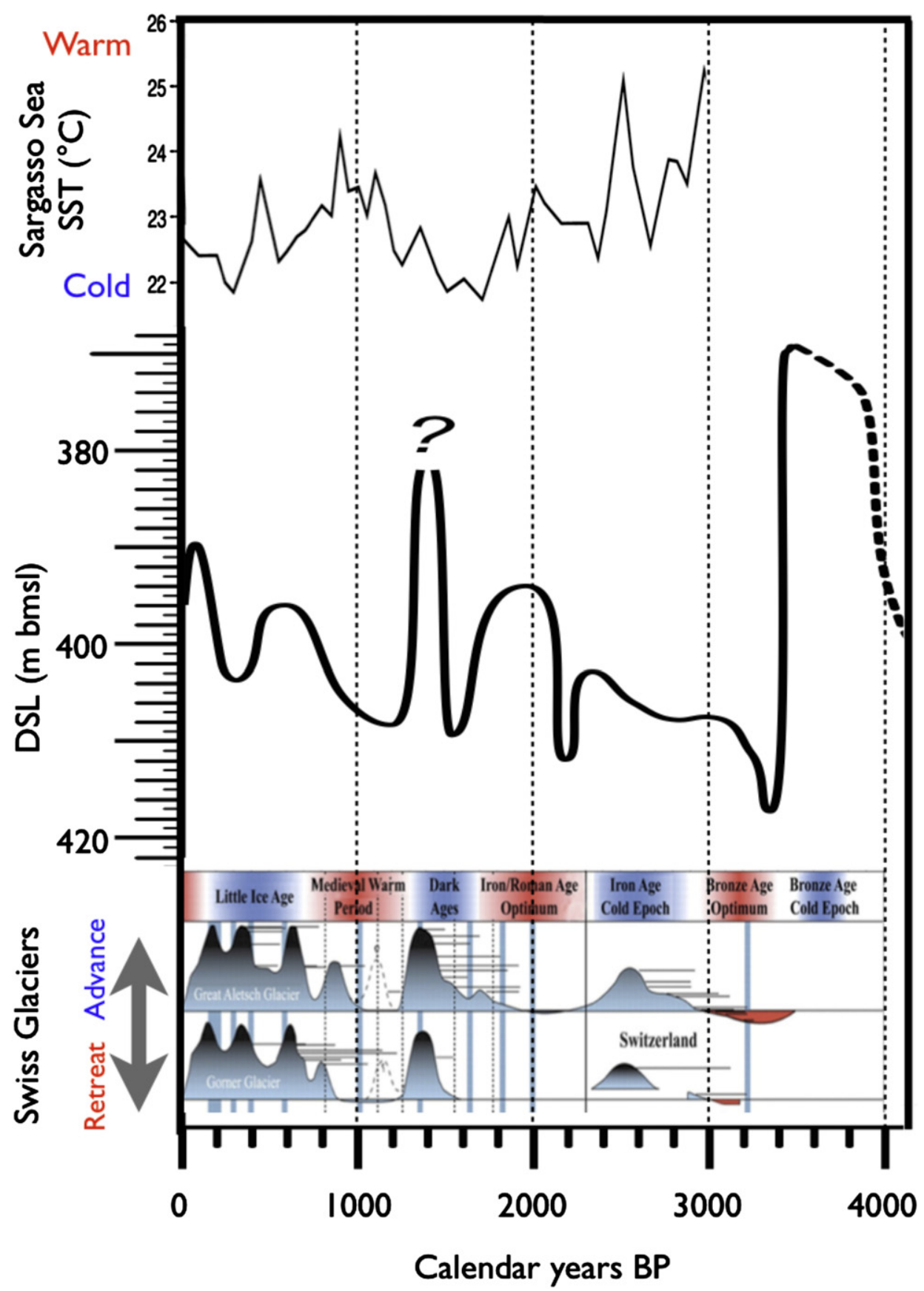

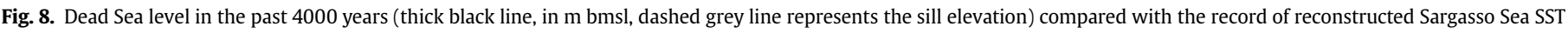

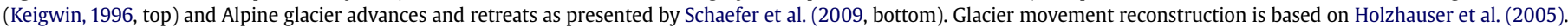
Denton and Broecker (2008) argue that glacier advances occur in association with cold North Atlantic SSTs.

oscillations until the mid-20th century, when its natural state was disrupted by human intervention.

Gradual wetting of the U.S. West climate in the mid to late Holocene, is evidence on the high activity of sand dunes in the Great Plains in the early Holocene compared to scant activity in the more recent half of the epoch (Forman et al., 2001). Moreover, the large, glacial period lakes in Western North America such as Estancia, Lahontan, and Mono Lake, declined upon the transition from the last glacial maximum to the post-glacial and early Holocene periods (e.g., Quade and Broecker, 2009) and (in the case of Estancia and Mono Lakes) have somewhat recovered in the midHolocene (Stine, 1990; Menking and Anderson, 2003). Overall this evolution parallels the gradual wetting of the Levant including the timing of maximum drying after the end of the YD.

In a broad overview therefore, we can divide the Holocene post the YD cold interval - into two parts: an early half, between 11 and 6 ka BP, when the Dead Sea levels, on average, were below the sill and a recent half, after 6 ka BP, when the levels were, on average above the sill. These changes occurred as the climate of subSaharan North Africa was changing from a wet to a dry state, western North America experienced gradual wetting, and the NAtl Ocean, particularly on its eastern side, cooled by $\sim 3^{\circ} \mathrm{C}$. This epochlong anti-phase relationship with the Sahel and with NAtl SSTs and in-phase relationship with North America is thus consistent with 


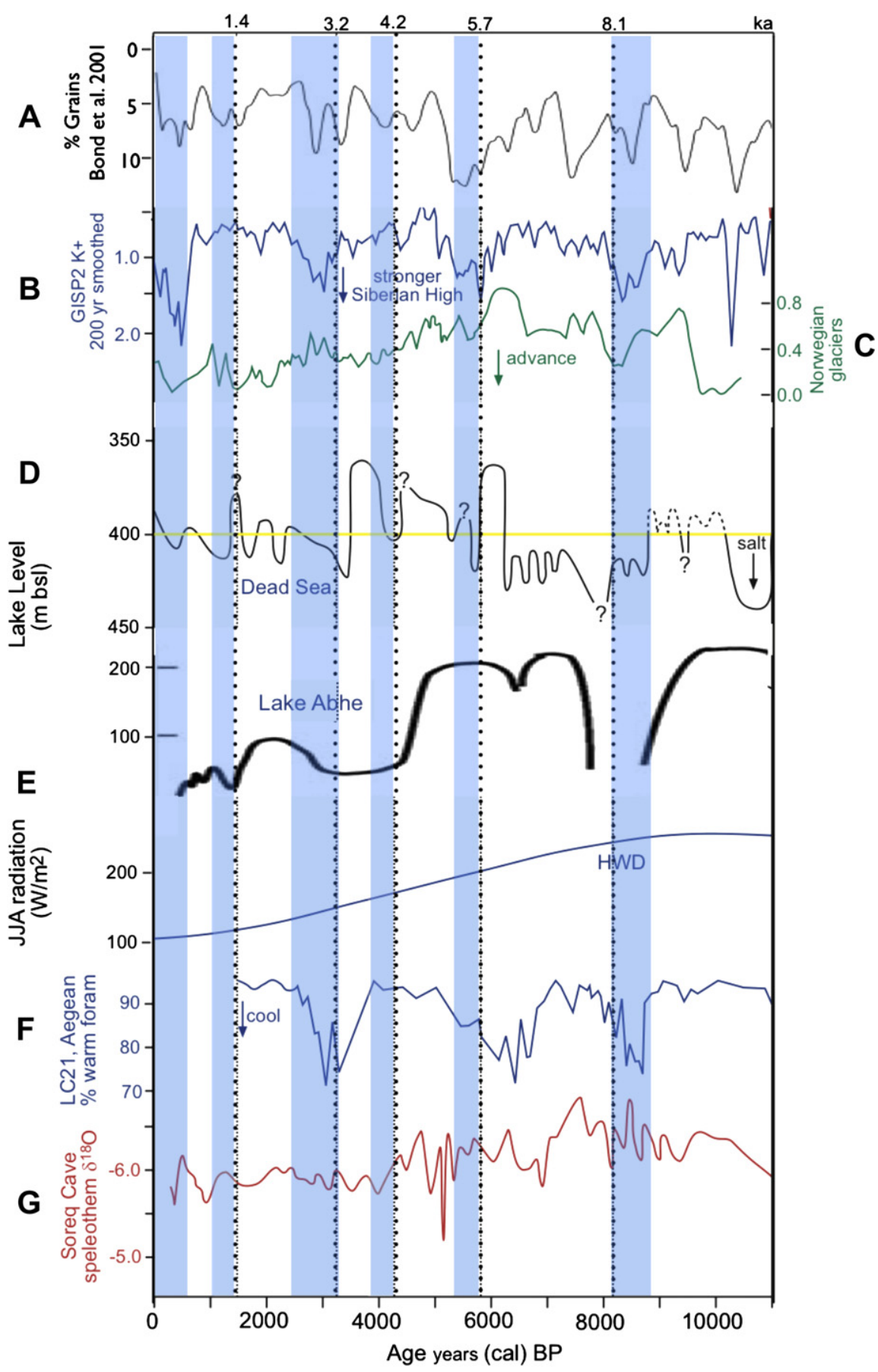

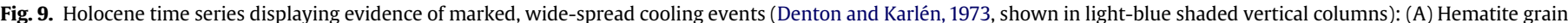

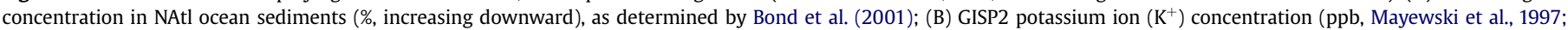

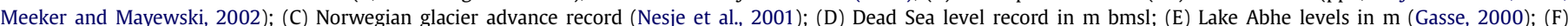

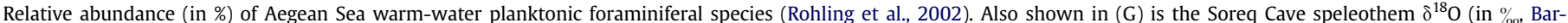

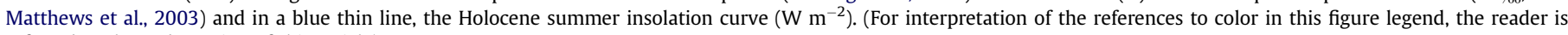
referred to the web version of this article).

the same phase relationships exhibited by the multidecadal changes found in the 19th and 20th century records.

\subsection{Holocene centennial to millennial time-scale climate variability}

Additional paleo-proxy evidence for the instrumental era phase relationships between hydroclimatic variations in the Dead Sea watershed region and remote locations, which points at the
Atlantic as orchestrating variations, comes from observing the Holocene centennial to millennial fluctuations. The Holocene Levant and Sahel paleo-records presented in Fig. 7 exhibit large fluctuations on these time scales and as we argue below, these changes continue to display the same associations found in the modern era. In attempting to compare the difference proxy records, in this subsection and in the next, we note that these records are derived using different methodologies, over land and in the marine 
environment. They thus display differences in dating precision, which limit the degree of confidence one can have in relating them to one another, particularly when discussing relatively short time-scale variations. We do however assume that these records represent the best-calibrated dating information. We focus on broad features and are directed by the hypothesis based on instrumental observations discussed in Section 3 above.

Scrutinizing the proxy records of millennial time-scale hydroclimatic variations in North African lake levels we recognize the remarkable synchronicity between the Chad Basin record in West Africa and those in the Ethiopian lakes in the East (Fig. 7d-f). This synchronicity is consistent with the coherent temporal behavior of instrumental precipitation records in the Sahel during the 20th century (Nicholson, 1986).

When comparing the DSL record to the level variations in African lakes in Fig. $7 \mathrm{~g}$ we have to take into account that there are significant differences in the methodology and dating accuracy of the lakelevel retrievals and in the records' temporal resolution. Within these limitations, we find that the anti-phase behavior in lake level variability is apparent also in these millennial fluctuations. For example, during the Bölling-Alleröd ( 14-13 ka BP) and the YD, when the DSL dropped precipitously and then rose above the sill level, respectively, the African hydroclimatic indicators (terrigenous dust record included) swung the other way - up and down. The subsequent millennial swings during the AHP and during the period of African lake decline also suggest an anti-phase relationship.

The relationship between centennial to millennial variability in the Levant and Sahel records and NAtl SST fluctuations on the same time scale is harder to discern with confidence from ocean sediment records, as these have a rather coarse and temporally uneven resolution. However, some support to our hypothesis emerges, particularly during the past few millennia. During the late Holocene, the Northern Hemisphere climate changed from the Medieval Climate Anomaly (MCA; 900-1400 AD), a relatively warm period in Europe and most likely the NAtl to the Little Ice Age (LIA, 1500-1900 AD), a cold period in these areas (see recent discussion by Denton and Broecker, 2008). Based on records of the advance and retreat of mountain glaciers in Europe and North America and historical evidence on the extent of wintertime sea ice coverage in the NAtl, Denton and Broecker (2008) argued for associated centennial time-scale variations in the strength of the AMOC and related SSTs (AMV) in the Basin. According to their synthesis the NAtl was relatively warm during the MCA and cold during the Little Ice Age. A comparison between the record of advances and retreat of Swiss Alpine glaciers and the DSL in the last 4000 years (Fig. 8) exhibits remarkable agreement between high lake stands and cold intervals in Europe. Consistent with the hypothesis of Denton and Broecker (2008) this lends support to our proposition regarding the role of the NAtl in Levant precipitation variability. A more direct indication to the variability of NAtl in the late Holocene comes from the Sargasso Sea SST reconstruction during the last 3000 years by Keigwin (1996). The time series (Fig. 8) displays centennial to millennial fluctuations of up to $1{ }^{\circ} \mathrm{C}$ superimposed on an overall cooling trend. An interval of relatively cold SSTs is seen in the Sargasso Sea series between $\sim 1.3$ and $\sim 2$ ka BP, when the late Holocene DSL reconstruction (Fig. 8) exhibits two intervals of relatively high (above sill) lake stands. Before $\sim 2 \mathrm{ka} B P$ the Sargasso SST record indicates a warm Atlantic that coincides with low DSL values, which are significantly below the sill. Low stands and warm Atlantic SSTs (according to Keigwin, 1996) are displayed between $\sim 800$ and $\sim 1300$ years BP (roughly overlapping the MCA). During this interval the low levels were associated with salt deposition in the northern Basin of the Dead Sea (Heim et al., 1997). About 800 years BP, Sargasso Sea SST cools again and the DSL oscillate up to a level of $\sim 390 \mathrm{~m}$ bmsl in the 19th century.
In the Sahel, following the demise of the AHP, indications of hydroclimate variability (normally derived from lake levels) are less available because of the general aridity of the region. However, Brooks (2004) provides a summary of the scant available information in the late Holocene. He indicates that following an interval of extreme desiccation between $\sim 300 \mathrm{BC}$ and $300 \mathrm{AD}$, corresponding mainly during its last part to an interval of relatively high DSLs. Subsequently, there is evidence for a relatively wet interval in the Sahel, extending until $\sim 1100 \mathrm{AD}$, and a progressive desiccation into the Little Ice Age that contrasts with the behavior of the DSL. The North American hydroclimatic proxy record, constructed from tree-ring chronologies, varies in phase with the Dead Sea, indicating that the American West experienced a dry Medieval climate and a wet Little Ice Age (Cook et al., 2004, 2007).

\subsection{Abrupt hydroclimatic events in the Holocene Levant}

The overall pattern of lake level behavior discussed above, is punctuated by several large and abrupt lake drops of tens of meters at about 8.4, 8.2, 5.7, 4.1, 3.2, and $1.4 \mathrm{ka}$ BP (Fig. 9). All these abrupt drops lie within the time intervals defined by Mayewski et al. (2004) as rapid climate change events (RCCs, indicated by vertical light-blue shaded bands in Fig. 9). As argued by Mayewski et al. (2004) based on an extensive review of global Holocene proxy records, these RCCs were associated with marked cold intervals in the North Atlantic, which impacted the surrounding land and sea regions. Mayewski et al. based their definition of the RCCs on an earlier seminal review of global Holocene mountain glacier expansion and contraction by Denton and Karlén (1973) with the RCCs corresponding to marked glacier advances mostly in North America and Europe.

The RCCs left their imprint on several marine paleoclimate archives from the Mediterranean. Significant ocean temperature changes, indicative of abrupt cooling events, were found in the Western Basin (Alboran and Tyrrhenian Seas, Cacho et al., 2001, 2002) and in the East (Aegean Sea, Casford et al., 2001; Rohling et al., 2002; Marino et al., 2009). As indicated in all these references (and see also Mayewski et al., 2004), the Mediterranean abrupt cooling events coincide with abrupt cooling in the NAtl region. They resemble much larger abrupt cooling events during the glacial era, which coincide with the Heinrich events documented in the Greenland ice cores. The strong glacial and milder Holocene abrupt cooling events are thought to result from strong, cold and dry wind outbreaks from the continent to the north which cool the surface temperatures and induce deep convection in the sea (Rohling et al., 1998; Cacho et al., 2001, 2002; Frigola et al., 2007; Kuhlemann et al., 2008).

Fig. 9 presents the Aegean Sea winter SST time series from Rohling et al. (2002) as well as time series of three NAtl indicators: the hematite grain concentration from Bond et al. (2001), the GISP2 potassium ion $\left(\mathrm{K}^{+}\right)$concentration (Mayewski et al., 1997), and the Norwegian glacier extent (Nesje et al., 2001), to emphasize the link between the NAtl, the EM and the Levant. Large hematite grain concentrations provide evidence for extensive ice rafting in the northern NAtl, presumed associated with marked cold intervals. The $\mathrm{K}^{+}$record was interpreted as evidence for changes in the intensity of the Siberian High (Meeker and Mayewski, 2002), a boreal winter phenomenon, which in the present climate is centered over Mongolia and normally extends westward to the Black Sea. The agreement between the time series, which relates abrupt and significant NAtl cooling to EM sea surface cooling and to abrupt DSL falls, is remarkable considering the different methods and dating accuracies. In this respect, we note that the general pattern of oxygen isotope in the East Mediterranean seawater, as reflected in the Judea Mt speleothem record and the Dead Sea 
aragonite (Kolodny et al., 2005; Almogi-Labin et al., 2009), does not follow the pattern of the abrupt NAtl or Mediterranean cold events. As we argued earlier (Section 4.1) these $\delta^{18} \mathrm{O}$ time series reflect the freshening of the EM source water for Levant rainfall due to enhanced flow of Nile River water during the AHP.

The most pronounced of the RCC events is the $\sim 8.2-8.1 \mathrm{ka} \mathrm{BP}$ that is also expressed by stronger cold excursion in the Greenland ice cores (see e.g., Mayewski et al., 2004). The event is well expressed in the Bond et al. (2001) grain count, the GISP2 $\mathrm{K}^{+}$record and the Norwegian glacier record (Mayewski et al., 2004 and see Fig. 9), as well as in the Aegean Sea (Rohling et al., 2002; Marino et al., 2009). In these Holocene records the events seem to span a broader time interval and begin a few centuries before the peak in the Greenland ice core. In particular, we note that in the GISP2 $\mathrm{K}^{+}$ record, the increase in ion concentration begins at around $8.7 \mathrm{ka} \mathrm{BP}$, as does the decrease in percent warm-water forams in the LC21 site at the boundary between the EM Basin and the Aegean Sea (see detailed discussions in Rohling and Palike, 2005 and Marino et al., 2009). In that respect, we note that DSL exhibits a two stage drop, a drop to $\sim 14 \mathrm{~m}$ below sill level begun already at $\sim 8.7 \mathrm{ka}$ BP followed by a possibly more precipitous drop at $\sim 8.1 \mathrm{ka}$ BP.

Within the uncertainties of the chronologies, the abrupt DSL drop associated with the $\sim 8.1 \mathrm{ka}$ event, coincides with the time interval associated with a significant drop in the Sahel Lake Abhe level (Figs. 7 and 9). Thus, it appears that the most significant abrupt climate events in the NAtl, such as the $\sim 8.1 \mathrm{ka}$ event lead to a significant extension of the margins of the desert belt over both south into the Sahel and North into the Levant. Further assessment of this important impact of the RCCs requires, however, additional evidence and a better chronology for the Sahelian lakes.

\section{Mechanisms}

The wide range of DSL fluctuations during the Holocene, in relation to NAtl, and African, European, and other Mediterranean climate proxy indicators, raises the question of whether all of them can be accommodated within a uniform controlling climate mechanism that is also consistent with the instrumental record.
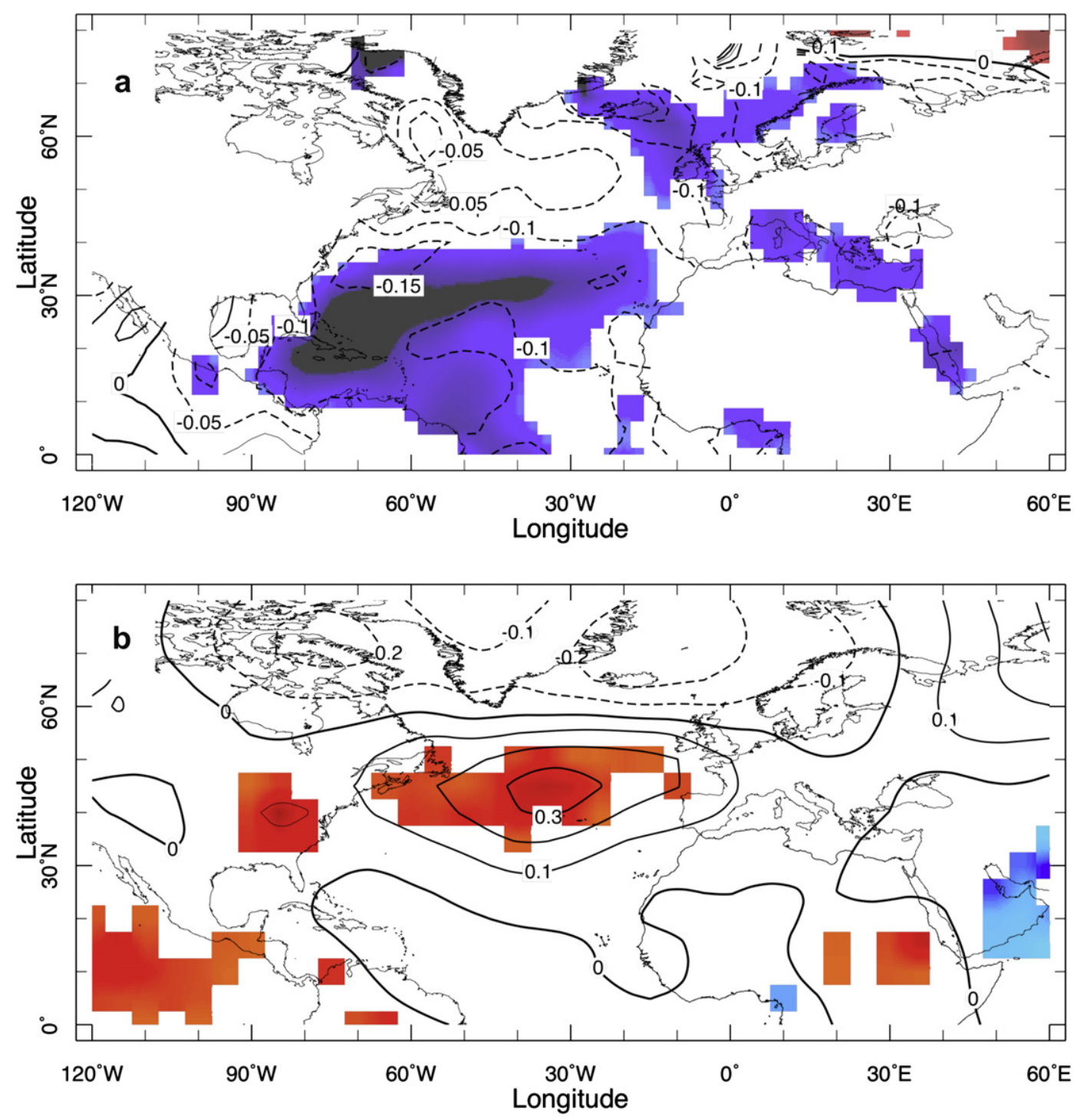

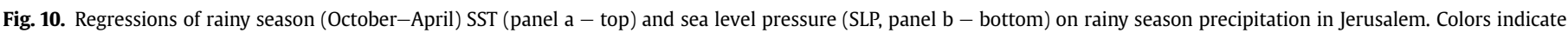

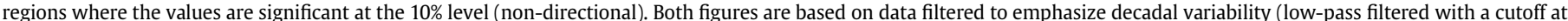

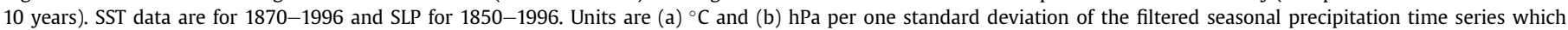
amounts to $\sim 110 \mathrm{~mm}$ (the standard deviation of the unfiltered seasonal rainfall in Jerusalem is $\sim 190 \mathrm{~mm}$ ). 
The response of African climate to changes to precession-cycle insolation variability was addressed in various numerical modeling studies (e.g., Kutzbach, 1981; Kutzbach and Liu, 1997; Ganopolski et al., 1998; Liu et al., 2004, 2007; Lorenz et al., 2006; Braconnot et al., 2007). These studies indicate that compared to the present summertime insolation (Northern Hemisphere minimum), the early- to mid-Holocene high summertime insolation (Northern Hemisphere maximum) forced a considerably more intense monsoonal rainfall which was spread further northward over Sahara desert, in agreement with a range of paleoclimate proxies. These modeling studies also show that the hydroclimatic response depends not only on the larger surface heating but also on land surface interactions, particularly a positive vegetation feedback and also, importantly, on a positive feedback due to the ocean response, particularly the warming of most of the NAtl (Liu et al., 2004). Coupled climate models forced with mid-Holocene insolation show that summer mean SSTs in the mid- and high-latitude NAtl were higher than at present day (an insolation minimum) by $0.25-1{ }^{\circ} \mathrm{C}$. The high latitudes appear warmer than the tropics though the pattern and strength of the response are somewhat dependent on the model (Liu et al., 2003; Lorenz et al., 2006; Braconnot et al., 2007). During the Levant rainy season - i.e., winter - precessioncycle insolation is at a minimum when summertime insolation is at its maximum. Thus the early- and mid-Holocene land surface in the Northern Hemisphere winter was probably colder than normal. The response of the ocean however, is less severe, leading to higher land-ocean surface temperature contrast than at present (Kutzbach et al., 1996). Some models persist the insolation-peak summertime SST warming into winter in the eastern NAtl and in the tropics (Liu et al., 2003; Lorenz et al., 2006), thus suggesting the warming impact of enhanced insolation is felt year-round.

Oceanic forcing was the main driver of variations in Sahel precipitation during the 20th Century (Folland et al., 1986; Giannini et al., 2003, 2008; Held et al., 2005; Lu and Delworth, 2005; Zhang and Delworth, 2006; Hoerling et al., 2006) and must also have been an important driver of the Holocene centennial to millennial fluctuations recorded in African lake levels, which are superimposed on the epochal drying of the region (Fig. 7). The modeling studies listed above show that the significant Sahel drying in the second half of the 20th century was driven by tropical warming and the increase interhemispheric SST contrast in the Atlantic, associated with the cooling north of the equator and the warming to the south. The mechanism through which a basin-wide and relatively mild change in the Atlantic interhemispheric SST gradient affects the intensity of the African summer monsoon most likely involves an influence on the extent of latitudinal migration and the intensity of the Intertropical Convergence Zone (ITCZ), which is connected with the poleward extent and intensity of the monsoonal rains over land. From coupled climate models we learn that the similar changes happen in unforced simulations (Knight et al., 2006) and that the SST variability itself is associated with fluctuations in the Atlantic Meridional Overturning Circulation (see also Delworth et al., 1993; Grotzner et al., 1999; Knight et al., 2005). A similar conclusion can be reached from paleoclimate proxies indicative of abrupt climate change and from climate model experiments that are meant to simulate such events by externally imposing a shutdown of the Atlantic Meridional Overturning Circulation (Vellinga and Wood, 2002; Chiang et al., 2003; Chiang and Bitz, 2005; Zhang and Delworth, 2005).

The influence of AMV on wintertime Levant hydroclimate has not been explored in past studies. We can however draw some relevant conclusions regarding the nature of this remote interaction from two sources, one linking precipitation variability in the Levant to changes in the regional atmospheric circulation and the other linking the AMV to the latter. First we note that Levant precipitation is closely linked with a seesaw in pressure between the eastern NAtl and Eurasia as re-iterated in Ziv et al. (2006, see Section 3 above). That study showed that rainy winters in the

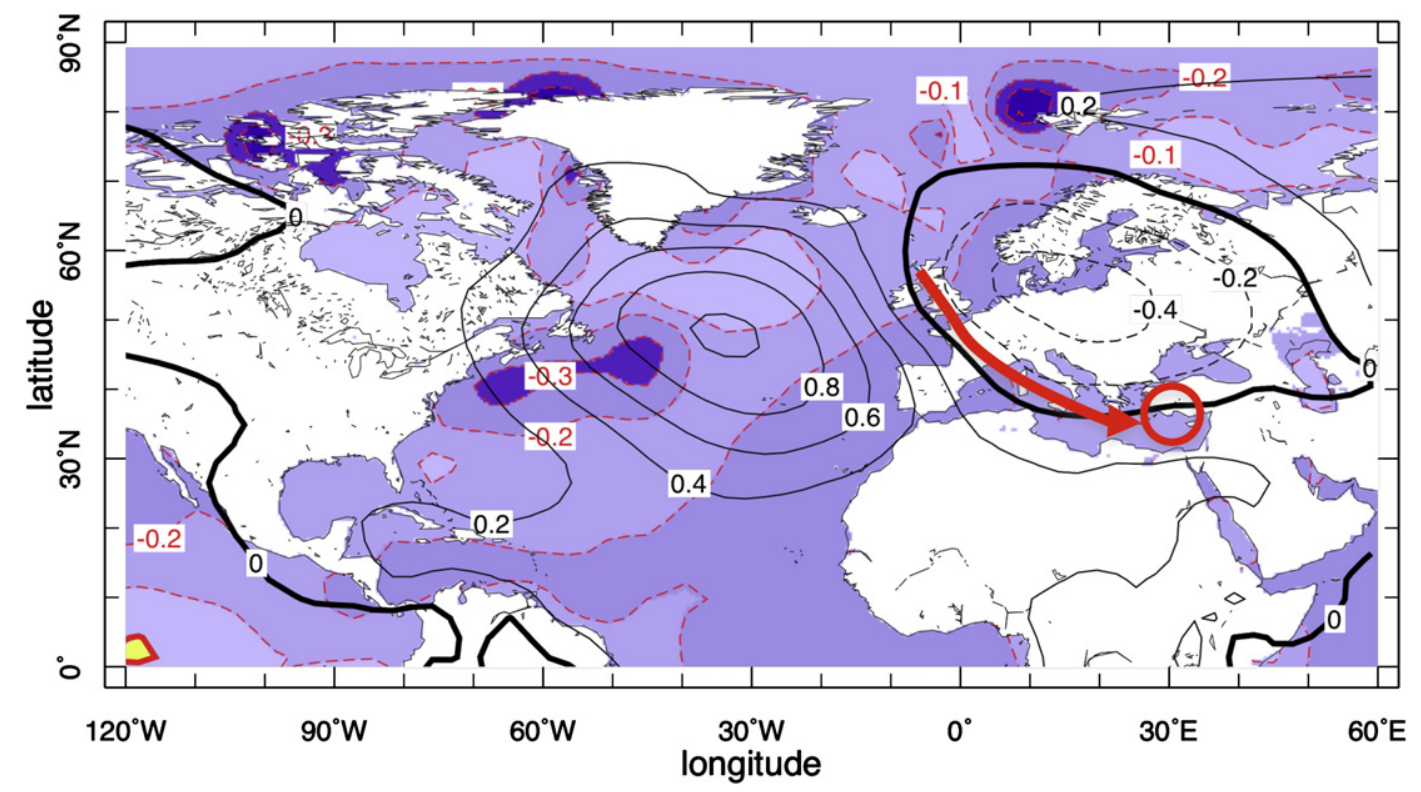

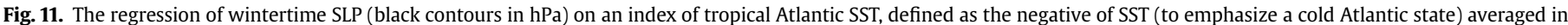

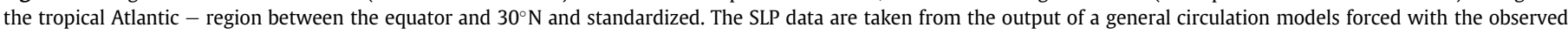

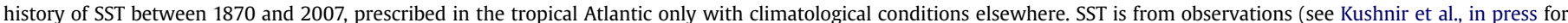

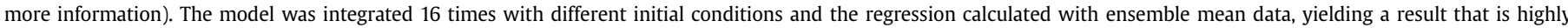

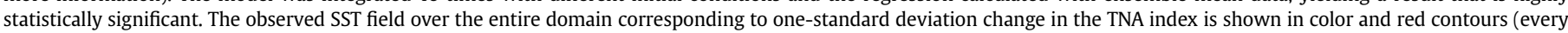

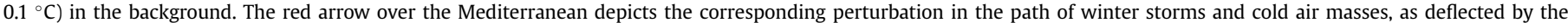
changes in the atmospheric circulation, which would subsequently lead to cyclogenesis in the Eastern Mediterranean (red circle) and rainfall in the Levant. 
Levant are associated with higher than normal sea level pressure (SLP) over the eastern NAtl extending into Western Europe and vice versa. Second is the apparent link between AMV and the atmospheric circulation as discussed e.g., in Kushnir (1994). That study showed that a positive-negative AMV composite (warm-cold SST in the NAtl), exhibits a negative sea level pressure (SLP) anomaly over the midlatitude NAtl, between 30 and $60^{\circ} \mathrm{N}$. The implication is that SLP is higher than normal in the middle of the NAtl and over Western Europe when the basin is colder than normal (some coupled ocean-atmosphere models simulate this link, e.g., Latif et al., 2000; Knight et al., 2006). These observations are consistent with the association: cold NAtl - higher than normal precipitation in the Levant, though they don't provide a causal argument.

In Fig. 10 we present additional analysis to support this association, which is based on data covering a longer time interval than used in Ziv et al. (2006) and emphasizing the long, decadal time scale. Fig. 10a supports the claim that Levant precipitation is associated with changes in NAtl SSTs and provides more detailed information to that presented in Fig. 4a. We see that the most significant link between AMV and Jerusalem precipitation is associated with SST changes in the tropical NAtl region. Note that AMV links SST fluctuations in this region with SST variations elsewhere in the Basin (Kushnir, 1994; Knight et al., 2006; Ting et al., 2009). In Fig. 10b we show that decadal fluctuations of seasonal precipitation in the Jerusalem record are linked with changes in SLP in the midlatitude NAtl such that rainier seasons tend to occur when SLP is higher than normal in that part of the Basin.

Note that the anomalous SLP pattern in Fig. 10b represents an enhancement of the climatological winter wave pattern, typical to the NAtl-Mediterranean region. In that pattern (see Ziv et al., 2006) there is a ridge of high pressure over the eastern NAtl, extending towards the Western Mediterranean (WM) and into Spain and Morocco. A climatological low-pressure area exists over the rest of the Mediterranean region, from the Tyrrhenian Sea to the EM, marking the path of Mediterranean winter cyclones. The anomalous map indicates that when precipitation in Jerusalem is higher than the average, the ridge over the WM is stronger than normal and the low-pressure region is enhanced, particularly in the EM as shown also in Ziv et al. (2006) using a much shorter record.

The regression patterns shown in Fig. 10 do not prove that the cold SSTs (Fig. 10a) are forcing the anomalous SLP pattern (Fig. 10b). Such conclusion cannot be drawn from a simultaneous association such as described above. To support a causal argument we turn to climate model experiments forced with prescribed SST variations such as discussed recently in Sutton and Hodson $(2003,2007)$ and in Kushnir et al. (in press). These studies investigate the role of Atlantic SST variability, AMV in particular, in influencing precipitation variability in western North America and Mexico. Both these studies imply that NAtl SSTs, particularly in the tropical region, force changes in the atmospheric circulation such that when these SSTs are colder than normal, SLP in the middle of the NAtl Basin is above normal and western North America is wetter than normal (and vice versa). This situation is depicted in Fig. 11, which shows the response of the general circulation model used in Kushnir et al. (in press) to SST anomalies, prescribed in the tropical NAtl region. Note that the response to SSTs prescribed in the entire NAtl Basin is not much different from that shown in Fig. 11 (see Sutton and Hodson, 2003, 2007; Kushnir et al., in press for mode details). There is a remarkable similarity between the observed SLP changes associated with wetter winters in Jerusalem in Fig. 10b and the model response to cold SSTs in the tropical Atlantic in Fig. 11. This similarity points more directly at a causal link between Atlantic SSTs to Levant precipitation.

To summarize: We propose that colder than normal SSTs in the NAtl, particularly in the east and subtropical region, lead to higher than normal SLP in the mid-NAtl Basin, during the cold season. This long-wave pattern deflects the extratropical storms from their normal tracks increasing the chances of polar air intrusions directly into the Eastern Mediterranean and, in turn, leads to higher likelihood for cyclogenesis and consequently higher precipitation in the Levant. Conversely, when Atlantic SSTs are higher than normal, lower than normal SLP in the mid-NAtl Basin brings warm air from a subtropical origin to the Eastern Mediterranean reducing the chances of cyclogenesis and consequently leads to a dryer than normal winter in the Levant. Overall, the influence of the AMV in the Levant is not strong enough to unambiguously control the higher frequency, year-to-year precipitation variability but it can tilt the balance of interannual variability one way or the other depending on the long-term state of the NAtl SSTs. The EM winter environment, with the large temperature contrast between the cold Eurasian continent and the warm sea and the Anatolian topography to the north, create unique conditions that amplify the Atlantic impact compared to other parts of the Mediterranean.

How can the abrupt drops in lake level, discussed in Section 4.3 and found associated with extreme cold NAtl events, be reconciled with the model proposed above? We note, that these events are expressed by the occurrence of strong marine convection in the WM (Gulf of Lion and Tyrrhenian Sea), linked with strong cold air outbreaks over the region (Rohling et al., 1998; Frigola et al., 2007; Kuhlemann et al., 2008). Such circumstances fit well with the model that cold SST in the NAtl lead to a formation of high pressure over the East Atlantic/Western Europe. As indicated above (Section 4.3) the abrupt events were also associated with marked cold outbreaks in the Aegean Sea (Marino et al., 2009), which could indicate that in these cases the East Atlantic/West Europe highpressure system was far more intense and spread further east, thus changing the nature of EM cyclogenesis process. It is possible that the hydrological impact in the central Levant depends critically on the EM wintertime air-sea contrast. If during extreme wintertime cold air outbreaks, the sea surface cooled to deep layers, its cold state would have persisted throughout summer. This would reduce the air-sea temperature contrast in the following winter, leading to reduced evaporation and reduced precipitation over land. If this situation lasted for years and decades, the Dead Sea watershed area would have experienced an extended interval of precipitation deficit, resulting in lake levels drops. This argument is similar to the one proposed by Bartov et al. (2003) to explain the abrupt drops of 50-70 m that are recorded in the last glacial Lake Lisan, which coincided with the glacial H-events in the NAtl. Unfortunately, such extreme events have no clear analog in the instrumental record and thus these ideas cannot be verified by observational analysis. The matter thus requires more careful study of well-dated proxy evidence.

\section{Summary}

Hydroclimate variability in the central Levant, specifically the Dead Sea watershed region, during the past 100 years, the past millennium, and the entire Holocene is examined in terms of its link to other global hydroclimatic indicators, using instrumental observations of precipitation and paleoclimate reconstruction. In the central Levant, in particular, the DSL record is used as a gauge for paleo-precipitation variations. The following observations and conclusions are noted:

1. In the instrumental record of the 19th and 20th centuries, a long-term, decade-to-century anti-phase relationship exists between winter precipitation in the central Levant and summer precipitation in the sub-Saharan Sahel, which is linked with the multidecadal variations in NAtl SST. 
2. On epochal time scales, the DSL appears to vary in response to the Holocene summer insolation change, related to the precession cycle. Consistently, DSLs were generally low at the beginning of the Holocene, during the AHP and the corresponding peak levels of the Sahelian lakes. In the mid- to lateHolocene, when the AHP terminated, DSLs rose to a marked Holocene peak and stayed generally high to the 20th century. During the entire epoch, the NAtl went through a gradual cooling, evident in alkenone thermometry from many ocean sites.

3. An examination of the DSL proxy record and its relationship to Sahel lake records, suggests that the anti-phase relationship and the connection to Atlantic SST is also present on centennial to millennial time scales through the entire Holocene.

4. The link between the Levant and Sahel regions is most likely orchestrated by the long-term (multidecadal to millennial) variability of SSTs in the NAtl, such when the Basin is relatively cold, the Sahel is relatively dry and the Levant relatively wet and vice versa.

5. This link is further reinforced by observational and proxy evidence (albeit scant) of an in-phase association between DSL variations and changes in precipitation in the American West, a region which is also know to be affected by the long-term variability of NAtl. SSTs.

6. We propose that NAtl SSTs affects the hydroclimate of the central Levant through inducing an atmospheric response over the Basin, with cold (warm) SSTs leading to the formation of a wintertime high (low) pressure in the Eastern NAtl extending over Western Europe and the WM. This response establishes a "bridge" to the EM consisting of a typical, regional atmospheric long-wave pattern in which the prevalence of high (low) pressure in the WM/East Atlantic is conducive to the formation of low (high) pressure in the EM, associated with rain bearing cyclonic systems (or the lack thereof).

7. Marked Holocene arid events, which are expressed as abrupt and relatively large drops (order of $10 \mathrm{~m}$ or more) in the DSL occur at $\sim 8.4,8.1,5.7,4.1,3.2$, and $1.4 \mathrm{ka}$ (cal) BP. In divergence with the climatic linkages described in points $1-6$ above, we find that the abrupt events are correlated with pronounced cooling episodes recorded in EM winter SSTs (reconstructed from planktonic foraminifera in marine cores) and with cold events in the northern latitudes (e.g., as Bond ice-rafting events). Thus it appears that unusually and abrupt large Northern Hemisphere cold episodes lead to the opposite effect than that of the milder and more slowly paced variability of the Holocene, suggesting a perplexing non-linearity in the regions response to global climatic events.

These results are important for projecting the future climate of the EM (and the Sahel). Specifically, AMV, which is a naturally occurring fluctuation, can either exacerbate or alleviate the projected monotonic drying trend forced by the increase of greenhouse gas concentrations depending on its phase.

\section{Acknowledgements}

The ideas and models expressed in this paper were developed during the sabbatical stay of M. Stein at Lamont. We enjoyed and benefited the constructive and illuminating conversations with Wally Broecker, Steve Goldstein, Adi Torfstein, and Baruch Ziv. Thanks also to our two reviewers, Eelco Rohling and Françoise Gasse, for their constructive criticism and excellent suggestions for improving the manuscript. The work was supported by NOAA awards NA03OAR4320179 and NA08OAR4320912 to Y. Kushnir and by the U.S.-Israel Binational Science Foundation (BSF) grant
\#2006363 to M, Stein. This is Lamont-Doherty Earth Observatory contribution number 7395 .

\section{References}

Adamson, D.A., Gasse, F., Street, F.A., Williams, M.A.J., 1980. Late Quaternary history of the Nile. Nature 288 (5786), 50-55.

Almogi-Labin, A., Bar-Matthews, M., Shriki, D., Kolosovsky, E., Paterne, M. Schilman, B., Ayalon, A., Aizenshtat, Z., Matthews, A., 2009. Climatic variability during the last similar to $90 \mathrm{ka}$ of the southern and northern Levantine Basin as evident from marine records and speleothems. Quaternary Science Reviews 28 (25-26), 2882-2896

Arz, H.W., Lamy, F., Patzold, J., Muller, P.J., Prins, M., 2003. Mediterranean moisture source for an early-Holocene humid period in the northern Red Sea. Science 300 (5616), 118-121.

Abu Ghazleh, S., Hartmann, J., Jansen, N., Kempe, S., 2009. Water input requirements of the rapidly shrinking Dead Sea. Naturwissenschaften 96, 637-643.

Asmar, B.N., Ergenzinger, B., 1999. Estimation of evaporation from the Dead Sea Hydrological Processes 13, 2743-2750.

Bar-Matthews, M., Ayalon, A., Kaufman, A., 2000. Timing and hydrological conditions of Sapropel events in the Eastern Mediterranean, as evident from speleothems, Soreq cave, Israel. Chemical Geology 169 (1-2), 145-156.

Bar-Matthews, M., Ayalon, A., Gilmour, M, Matthews, A., Hawkes- worth, C.J., 2003. Sea-land oxygen isotopic relationships from planktonic foraminifera and speleothems in the Eastern Mediterranean region and their implication for paleorainfall during interglacial intervals. Geochimica et Cosmochimica Acta 67 (17), 3181-3199.

Barnston, A., Livezey, R.E., 1987. Classification, seasonality and persistence of lowfrequency circulation patterns. Monthly Weather Review 115, 1083-1126.

Bartov, Y., Stein, M., Enzel, Y., Agnon, A., Reches, Z., 2002. Lake levels and sequence stratigraphy of Lake Lisan, the late Pleistocene precursor of the Dead Sea. Quaternary Research 57 (1), 9-21.

Bartov, Y., Goldstein, S.L., Stein, M., Enzel, Y., 2003. Catastrophic arid episodes in the eastern Mediterranean linked with the north Atlantic Heinrich events. Geology 31 (5), 439-442.

Bartov, Y., Enzel, Y., Porat, N., Stein, M., 2007. Evolution of the late pleistoceneholocene dead sea basin from sequence statigraphy of fan deltas and lake-level reconstruction. Journal of Sedimentary Research 77 (9-10), 680-692.

Beck, C., Grieser, J., Rudolf, B., 2005. A new monthly precipitation climatology for the Global Land Areas for the period 1951 to 2000. DWD, Klimastatusbericht KSB. ISSN: 1437-7691 ISSN: 1437-7691, 181-190. http://gpcc.dwd.de/. 2004ISSN 1616-5063 (Internet), ISBN 3-88148-402-7.

Begin, B., Ehrlich, A., Nathan, Y., 1974. Lake Lisan, the Pleistocene precursor of the Dead Sea. Geological Survey of Israel Bulletin 63, 30.

Berger, A., Loutre, M.F., 1991. Insolation values for the climate of the last 10000000 years. Quaternary Science Reviews 10 (4), 297-317.

Bond, G., Kromer, B., Beer, J., Muscheler, R., Evans, M.N., Showers, W., Hoffmann, S. Lotti-Bond, R., Hajdas, I., Bonani, G., 2001. Persistent solar influence on north Atlantic climate during the Holocene. Science 294 (5549), 2130-2136.

Bookman (Ken-Tor), R., Enzel, Y., Agnon, A., Stein, M., 2004. Late Holocene lake levels of the Dead Sea. Geological Society of America Bulletin 116 (5-6), 555-571.

Bookman (Ken-Tor), R., Lazar, B., Stein, M., Burr, G.S., 2007. Radiocarbon dating of primary aragonite by sequential extraction of $\mathrm{CO}_{2}$. Holocene 17 (1), 131-137.

Braconnot, P., Otto-Bliesner, B., Harrison, S., Joussaume, S., Peterchmitt, J.Y., AbeOuchi, A., Crucifix, M., Driesschaert, E., Fichefet, T., Hewitt, C.D., Kageyama, M., Kitoh, A., Laine, A., Loutre, M.F., Marti, O., Merkel, U., Ramstein, G., Valdes, P., Weber, S.L., Yu, Y., Zhao, Y., 2007. Results of PMIP2 coupled simulations of the Mid-Holocene and Last Glacial Maximum - Part 1: experiments and large-scale features. Climate of the Past 3 (2), 261-277.

Brooks, N., 2004. Drought in the African Sahel: Long Term Perspectives and Future Prospects. Tyndall Centre for Climate Change Research, University of East Anglia, Norwich, UK.

Cacho, I., Grimalt, J.O., Canals, M., Sbaffi, L, Shackleton, N.J. Schonfeld, J, Zahn, R. 2001. Variability of the western Mediterranean Sea surface temperature during the last 25,000 years and its connection with the Northern Hemisphere climatic changes. Paleoceanography 16 (1), 40-52.

Cacho, I., Grimalt, J.O., Canals, M., 2002. Response of the Western Mediterranean Sea to rapid climatic variability during the last 50,000 years: a molecular biomarker approach. Journal of Marine Systems 33, 253-272.

Casford, J.S.L., Abu-Zied, R., Rohling, E.J., Cooke, S., Boes-senkool, K.P., Brinkhuis, H., DeVries, C., Wefer, G., Geraga, M., Papatheodorou, G., Croudace, I., Thomson, J. Lykousis, V., 2001. Mediterranean climate variability during the Holocene. Mediterranean Marine Science 2 (1), 45-55.

Casford, J.S.L., Rohling, E.J., Abu-Zied, R.H., Fontanier, C., Jorissen, F.J., Leng, M.J., Schmiedl, G., Thomson, J., 2003. A dynamic concept for eastern Mediterranean circulation and oxygenation during sapropel formation. Palaeogeography, Palaeoclimatology, Palaeoecology 190, 103-119.

Chalie, F., Gasse, F., 2002. Late Glacial-Holocene diatom record of water chemistry and lake level change from the tropical East African Rift Lake Abiyata (Ethiopia) Palaeogeography, Palaeoclimatology, Palaeoecology 187 (3-4), 259-283. 
Chiang, J.C.H., Biasutti, M., Battisti, D.S., 2003. Sensitivity of the Atlantic intertropical convergence zone to Last Glacial Maximum boundary conditions. Paleoceanography 18 (4). doi:10.1029/2003PA000916.

Chiang, J.C.H., Bitz, C.M., 2005. Influence of high latitude ice cover on the marine Intertropical Convergence Zone. Climate Dynamics 25 (5), 477-496.

Christensen, J.H., Hewitson, B., Busuioc, A., Chen, A.A., Gao, X.J., Held, I., Jones, R., Kolli, R.K., Kwon, W.-T., Laprise, R., Magaña Rueda, V., Mearns, L., Menéndez, C.G., Räisänen, J., Rinke, A.A.S., Whetton, P., 2007. Regional climate projections. In: InSolomon, S., Qin, D., Manning, M., Chen, Z., Marquis, M., Averyt, K.B., Tignor, M., Miller, H.L. (Eds.), Climate Change 2007: The Physica Science Basis. Contribution of Working Group I to the Fourth Assessment Report of the Intergovernmental Panel on Climate Change. Cambridge University Press, Cambridge, United Kingdom and New York, NY, USA.

Cook, E.R., Woodhouse, C.A., Eakin, C.M., Meko, D.M., Stahle, D.W., 2004. Long-term aridity changes in the western United States. Science 306 (5698), 1015-1018.

Cook, E.R., Seager, R., Cane, M.A., Stahle, D.W., 2007. North American drought: reconstructions, causes, and consequences. Earth-Science Reviews 81 (1-2) 93-134.

Cullen, H.M., deMenocal, P.B., 2000. North Atlantic influence on Tigris-Euphrates streamflow. International Journal of Climatology 20 (8), 853-863.

Delworth, T., Manabe, S., Stouffer, R.J., 1993. Interdecadal variations of the thermohaline circulation in a coupled ocean-atmosphere model. Journal of Climate 6 (11), 1993-2011.

deMenocal, P., Ortiz, J., Guilderson, T., Adkins, J., Sarnthein, M., Baker, L. Yarusinsky, M., 2000. Abrupt onset and termination of the African Humid Period: rapid climate responses to gradual insolation forcing. Quaternary Science Reviews 19 (1-5), 347-361.

Denton, G.H., Karlén, W., 1973. Holocene climatic variations: their pattern and possible cause. Quaternary Research 3, 155-205.

Denton, G.H., Broecker, W.S., 2008. Wobbly ocean conveyor circulation during the Holocene? Quaternary Science Reviews 27 (21-22), 1939-1950.

Enfield, D.B., Mestas-Nunez, A.M., Trimble, P.J., 2001. The Atlantic multidecadal oscillation and its relation to rainfall and river flows in the continental U.S. Geophysical Research Letters 28 (10), 2077-2080.

Enzel, Y., Bookman, R., Sharon, D., Gvirtzman, H., Dayan, U., Ziv, B., Stein, M., 2003. Late Holocene climates of the Near East deduced from Dead Sea level variations and modem regional winter rainfall. Quaternary Research 60 (3), 263-273.

Folland, C.K., Palmer, T.N., Parker, D.E., 1986. Sahel rainfall and worldwide sea temperatures, 1901-85. Nature 320, 602-607.

Forman, S.L., Oglesby, R., Webb, R.S., 2001. Temporal and spatial patterns of Holocene dune activity on the Great Plains of North America: megadroughts and climate links. Global and Planetary Change 29 (1-2), 1-29.

Frigola, J., Moreno, A., Cacho, I., Canals, M., Sierro, F.J., Flores, J.A., Grimalt, J.O. Hodell, D.A., Curtis, J.H., 2007. Holocene climate variability in the western Mediterranean region from a deepwater sediment record. Paleoceanography 22 (2).

Ganopolski, A., Kubatzki, C., Claussen, M., Brovkin, V., Petoukhov, V., 1998. The influence of vegetation-atmosphere-ocean interaction on climate during the mid-Holocene. Science 280 (5371), 1916-1919.

Gasse, F., 2000. Hydrological changes in the African tropics since the Last Glacial Maximum. Quaternary Science Reviews 19 (1-5), 189-211.

Gasse, F., Roberts, C.N., 2005. Late quaternary hydrologic changes in the arid and semiarid belt of northern Africa: implications for past atmospheric circulation. In: Diaz, H.F., Bradley, R.S. (Eds.), The Hadley Circulation: Present, Past and Future. Kluwer Academic Publishers, pp. 313-345.

Giannini, A., Saravanan, R., Chang, P., 2003. Oceanic forcing of Sahel rainfall on interannual to interdecadal time scales. Science 302 (5647), 1027-1030.

Giannini, A., Biasutti, M., Held, I.M., Sobel, A.H., 2008. A global perspective on African climate. Climatic Change 90 (4), 359-383.

Graham, N.E., Hughes, M.K., Ammann, C.M., Cobb, K.M., Hoerling, M.P., Kennett, D.J., Kennett, J.P., Rein, B., Stott, L., Wigand, P.E., Xu, T.Y., 2007. Tropical Pacific - midlatitude teleconnections in medieval times. Climatic Change 83 (1-2), 241-285.

Gray, S.T., Fastie, C.L., Jackson, S.T., Betancourt, J.L., 2004. Tree-ring-based reconstruction of precipitation in the Bighorn Basin, Wyoming, since 1260 AD. Journal of Climate 17 (19), 3855-3865.

Gillespie, R., Streetperrott, F.A., Switsur, R., 1983. Post-Glacial arid episodes in Ethiopia have implications for climate prediction. Nature 306 (5944), 680-683.

Grotzner, A., Latif, M., Timmermann, A., Voss, R., 1999. Interannual to decada predictability in a coupled ocean-atmosphere general circulation model. Journal of Climate 12 (8), 2607-2624.

Haase-Schramm, A., Goldstein, S.L., Stein, M., 2004. U-Th dating of Lake Lisan (late Pleistocene Dead Sea) aragonite and implications for glacial East Mediterranean climate change. Geochimica Et Cosmochimica Acta 68 (5), 985-1005.

Hazan, N., Stein, M., Agnon, A., Marco, S., Nadel, D., Negendank, J.F.W., Schwab, M.J., Neev, D., 2005. The late quaternary limnological history of Lake Kinneret (Sea of Galilee), Israel. Quaternary Research 63 (1), 60-77.

Heim, C., Nowaczyk, N.R., Negendank, J.F.W., Leroy, S.A.G., Ben Avraham, Z., 1997. Near east desertification: evidence from the Dead Sea. Naturwissenschaften 84 (9), 398-401.

Held, I.M., Soden, B.J., 2006. Robust responses of the hydrological cycle to global warming. Journal of Climate 19 (21), 5686-5699.

Held, I.M., Delworth, T.L., Lu, J., Findell, K.L., Knutson, T.R., 2005. Simulation of Sahel drought in the 20th and 21st centuries. Proceedings of the National Academy of Sciences of the United States of America 103 (4), 1152-1153.
Hoelzmann, P., Jolly, D., Harrison, S.P., Laarif, F., Bonnefille, R., Pachur, H.J., 1998. MidHolocene land-surface conditions in northern Africa and the Arabian Peninsula: a data set for the analysis of biogeophysical feedbacks in the climate system. Global Biogeochemical Cycles 12 (1), 35-51.

Hoerling, M., Hurrell, J., Eischeid, J., Phillips, A., 2006. Detection and attribution of twentieth-century northern and southern African rainfall change. Journal of Climate 19 (16), 3989-4008.

Holzhauser, H., Magny, M., Zumbuhl, H.J., 2005. Glacier and lake-level variations in west-central Europe over the last 3500 years. Holocene 15 (6), 789-801.

Hurrell, J.W., Kushnir, Y., Ottersen, G., Visbeck, M., 2003. An overview of the North Atlantic Oscillation. In: Hurrell, J.W., Kushnir, Y., Ottersen, G., Visbeck, M. (Eds.), The North Atlantic Oscillation: Climatic Significance and Environmental Impact. American Geophysical Union, Washington, DC, pp. 1-35.

Iglesias, A., Garrote, L., Flores, L., Moneo, M., 2007. Challenges to manage the risk of water scarcity and climate change in the Mediterranean. Water Resources Management 21, 775-788.

IPCC, 2007. Climate change 2007: the physical science basis. In: Solomon, S., Qin, D., Manning, M., Chen, Z., Marquis, M., Averyt, K.B., Tignor, M., Miller, H.L. (Eds.), Contribution of Working Group I to the Fourth Assessment Report of the Intergovernmental Panel on Climate Change. Cambridge University Press, Cambridge, United Kingdom and New York, NY, USA, p. 996.

Keigwin, L.D., 1996. The Little Ice Age and Medieval warm period in the Sargasso Sea. Science 274 (5292), 1504-1508.

Kerr, R.A., 2000. A North Atlantic climate pacemaker for the centuries. Science 288, 1984-1985.

Kim, J.H., Meggers, H., Rimbu, N., Lohmann, G., Freudenthal, T., Muller, P.J., Schneider, R.R., 2007. Impacts of the North Atlantic gyre circulation on Holocene climate off northwest Africa. Geology 35 (5), 387-390.

Knight, J.R., Allan, R.J., Folland, C.K., Vellinga, M., Mann, M.E., 2005. A signature of persistent natural thermohaline circulation cycles in observed climate. Geophysical Research Letters 32 (20).

Knight, J.R., Folland, C.K., Scaife, A.A., 2006. Climate impacts of the Atlantic multidecadal oscillation. Geophysical Research Letters 33 (17).

Kolodny, Y., Stein, M., Machlus, M., 2005. Sea-Rain-Lake relation in the Last Glacial east Mediterranean revealed by a delta $\mathrm{O}-18$-delta $\mathrm{C}-13$ in Lake Lisan aragonites. Geochimica et Cosmochimica Acta 69 (16), 4045-4060.

Krichak, S.O., Tsidulko, M., Alpert, P., 2000. Monthly synoptic patterns associated with wet/dry conditions in the Eastern Mediterranean. Theoretical and Applied Climatology 65 (3-4), 215-229.

Kuhlemann, J., Rohling, E.J., Krumrei, I., Kubik, P., Ivy-Ochs, S., Kucera, M., 2008. Regional synthesis of Mediterranean atmospheric circulation during the last glacial maximum. Science 321 (5894), 1338-1340.

Kushnir, Y., 1994. Interdecadal variations in North-Atlantic sea-surface temperature and associated atmospheric conditions. Journal of Climate 7 (1), 141-157.

Kushnir, Y., Seager, R., Ting, M., Naik, N. and Nakamura, J. Mechanisms of tropical Atlantic SST influence on North American precipitation variability. Journal of Climate, in press., doi:10.1175/2010JCLI3172.1 (Early Online Release)

Kutzbach, J.E., 1981. Monsoon climate of the early Holocene - climate experiment with the earths orbital parameters for 9000 years ago. Science 214, 59-61.

Kutzbach, J.E., Liu, Z., 1997. Response of the African monsoon to orbital forcing and ocean feedbacks in the middle Holocene. Science 278, 440-443.

Kutzbach, J., Bonan, G., Foley, J., Harrison, S.P., 1996. Vegetation and soil feedbacks on the response of the African monsoon to orbital forcing in the early to middle Holocene. Nature 384 (6610), 623-626.

Latif, M., Arpe, K., Roeckner, E., 2000. Oceanic control of decadal North Atlantic sea level pressure variability in winter. Geophysical Research Letters 27 (5), $727-730$.

Lee, S., Kim, H.-K., 2003. The dynamic relationship between subtropical and eddydriven jets. Journal of Climate 60 (12), 1490-1503.

Liu, Z., Brady, E., Lynch-Stieglitz, J., 2003. Global ocean response to orbital forcing in the Holocene. Paleoceanography 18 (2). doi:10.1029/2002PA000819.

Liu, Z., Harrison, S.P., Kutzbach, J., Otto-Bliesner, B., 2004. Global monsoons in the mid-Holocene and oceanic feedback. Climate Dynamics 22, 157-182.

Liu, Z., Wang, Y., Gallimore, R., Gasse, F., Johnson, T., deMenocal, P., Adkins, J., Notaro, M., Prenticer, I.C., Kutzbach, J., Jacob, R., Behling, P., Wang, L., Ong, E., 2007. Simulating the transient evolution and abrupt change of Northern Africa atmosphere-ocean-terrestrial ecosystem in the Holocene. Quaternary Science Reviews 26, 1818-1837.

Lorenz, S.J., Kim, J.H., Rimbu, N., Schneider, R.R., Lohmann, G., 2006. Orbitally driven insolation forcing on Holocene climate trends: evidence from alkenone data and climate modeling. Paleoceanography 21 (1). doi:10.1029/2005PA001152.

Lu, J., Delworth, T.L., 2005. Oceanic forcing of the late 20th century Sahel drought Geophysical Research Letters 32 (22). doi:10.1029/2005GL023316.

Marino, G., Rohling, E.J., Sangiorgi, F., Hayes, A., Casford, J.L., Lotter, A.F., Kucera, M., Brinkhuis, H., 2009. Early and middle Holocene in the Aegean Sea: interplay between high and low latitude climate variability. Quaternary Science Reviews 28 (27-28), 3246-3262.

Mariotti, A., Zeng, N., Lau, K.M., 2002. Euro-Mediterranean rainfall and ENSO a seasonally varying relationship. Geophysical Research Letters 29 (12). doi:10.1029/2001GL014248.

Mariotti, A., Ballabrera-Poy, J., Zeng, N., 2005. Tropical influence on Euro-Asian autumn rainfall variability. Climate Dynamics 24 (5), 511-521.

Mariotti, A., Zeng, N., Yoon, J.-H., Artale, V., Navarra, A., Alpert, P., Li, L.Z.X., 2009. Mediterranean water cycle changes: transition to drier 21st century conditions 
in observations and CMIP3 simulations. Environmental Research Letters 3, 044001 (8pp.).

Marshall, J., Kushnir, Y., Battisti, D., Chang, P., Czaja, A., Dickson, R., Hurrell, J., McCartney, M., Saravanan, R., Visbeck, M., 2001. North Atlantic climate variability: phenomena, impacts and mechanisms. International Journal of Climatology 21, 1863-1898.

Mayewski, P.A., Meeker, L.D., Twickler, M.S., Whitlow, S., Yang, Q.Z., Lyons, W.B., Prentice, M., 1997. Major features and forcing of high-latitude northern hemisphere atmospheric circulation using a 110,000-year-long glaciochemical series. Journal of Geophysical Research-Oceans 102 (C12), 26345-26366.

Mayewski, P.A., Rohling, E.E., Stager, J.C., Karlen, W., Maasch, K.A., Meeker, L.D., Meyerson, E.A., Gasse, F., van Kreveld, S., Holmgren, K., Lee-Thorp, J. Rosqvist, G., Rack, F., Staubwasser, M., Schneider, R.R., Steig, E.J., 2004. Holocene climate variability. Quaternary Research 62 (3), 243-255.

McCabe, G.J., Palecki, M.A., 2006. Multidecadal climate variability of global lands and oceans. International Journal of Climatology 26 (7), 849-865.

McCabe, G.J., Palecki, M.A., Betancourt, J.L., 2004. Pacific and Atlantic Ocean influences on multidecadal drought frequency in the United States. Proceedings of the National Academy of Sciences of the United States of America 101 (12), 4136-4141.

Meehl, G.A., Stocker, T.F., Collins, W.D., Friedlingstein, P., Gaye, A.T., Gregory, J.M., Kitoh, A., Knutti, R., Murphy, J.M., Noda, A., Raper, S.C.B., Watterson, I.G., Weaver, A.J., Zhao, Z.-C., 2007. Global climate projections. In: Solomon, S. Qin, D., Manning, M., Chen, Z., Marquis, M., Averyt, K.B., Tignor, M., Miller, H.L. (Eds.), Climate Change 2007: The Physical Science Basis. Contribution of Working Group I to the Fourth Assessment Report of the Intergovernmental Panel on Climate Change. Cambridge University Press, Cambridge, United Kingdom/New York, NY, USA.

Meeker, L.D., Mayewski, P.A., 2002. A 1400-year high-resolution record of atmospheric circulation over the North Atlantic and Asia. Holocene 12 (3), 257-266.

Menking, K.M., Anderson, R.Y., 2003. Contributions of La Niña and El Niño to middle Holocene drought and late Holocene moisture in the American Southwest. Geology 31, 937-940.

Migowski, C., Stein, M., Prasad, S., Negendank, J.F.W., Agnon, A., 2006. Holocene climate variability and cultural evolution in the Near East from the Dead Sea sedimentary record. Quaternary Research 66 (3), 421-431.

Neev, D., Emery, K.O., 1967. The Dead Sea: Depositional Processes and Environments of Evaporites. Geological Survey of Israel, Jerusalem, Israel.

Neev, D., Emery, K.O., 1995. The Destruction of Sodom, Gomorrah, and Jericho. Oxford Univ. Press, New York, 175 pp.

Nesje, A., Matthews, J.A., Dahl, S.O., Berrisford, M.S., Andersson, C., 2001. Holocene glacier fluctuations of Flatbreen and winter-precipitation changes in the Jostedalsbreen region, western Norway, based on glaciolacustrine sediment records. Holocene 11, 267-280.

Nicholson, S.E., 1986. The spatial coherence of African rainfall anomalies - interhemispheric teleconnections. Journal of Climate and Applied Meteorology 25 (10), 1365-1381.

Price, C., Stone, L., Huppert, A., Rajagopalan, B., Alpert, P., 1998. A possible link between El Nino and precipitation in Israel. Geophysical Research Letters 25 (21), 3963-3966.

Quade, J., Broecker, W.S., 2009. Dryland hydrology in a warmer world: lessons from the Last Glacial period. European Physical Journal - Special Topics 176, 21-36.

Reynolds, R.W., Smith, T.M., 1994. Improved global sea-surface temperature analyses using optimum interpolation. Journal of Climate 7 (6), 929-948.

Rodwell, M.J., Hoskins, B.J., 1996. Monsoons and the dynamics of deserts. Quarterly Journal of the Royal Meteorological Society 122 (534), 1385-1404.

Rohling, E.J., 1994. Review and new aspects concerning the formation of eastern Mediterranean sapropels. Marine Geology 122 (1-2), 1-28.

Rohling, E.J., Hilgen, F.J., 1991. The eastern Mediterranean climate at times of sapropel formation - a review. Geologie En Mijnbouw 70 (3), 253-264.

Rohling, E.J., Palike, H., 2005. Centennial-scale climate cooling with a sudden cold event around 8,200 years ago. Nature 434 (7036), 975-979.

Rohling, E.J., Hayes, A., De Rijk, S., Kroon, D., Zachariasse, W.J., Eisma, D., 1998. Abrupt cold spells in the northwest Mediterranean. Paleoceanography 13 (4), 316-322.

Rohling, E.J., Mayewski, P.A., Abu-Zied, R.H., Casford, J.S.L., Hayes, A., 2002. Holocene atmosphere-ocean interactions: records from Greenland and the Aegean Sea. Climate Dynamics 18 (7), 587-593.

Rossignol-Strick, M., 1999. The Holocene climatic optimum and pollen records of sapropel 1 in the eastern Mediterranean, 9000-6000 BP. Quaternary Science Reviews 18 (4-5), 515-530.

Rossignol-Strick, M., Nesteroff, W., Olive, P., Vergnaud-Grazzini, C., 1982. After the deluge: Mediterranean stagnation and sapropel formation. Nature 295, 105-110. doi:10.1038/295105a0.
Schaefer, J.M., Denton, G.H., Kaplan, M., Putnam, A., Finkel, R.C., Barrell, D.J.A., Andersen, B.G., Schwartz, R., Mackintosh, A., Chinn, T., Schluchter, C., 2009 High-frequency Holocene glacier fluctuations in New Zealand differ from the northern signature. Science 324 (5927), 622-625. doi:10.1126/science.1169312.

Schlesinger, M.E., Ramankutty, N., 1994. An oscillation in the global climate system of period 65-70 Years. Nature 367 (6465), 723-726.

Seager, R., Harnik, N., Robinson, W.A., Kushnir, Y., Ting, M., Huang, H.P., Velez, J. 2005. Mechanisms of ENSO-forcing of hemispherically symmetric precipitation variability. Quarterly Journal of the Royal Meteorological Society 131 (608), 1501-1527.

Seager, R., Graham, N., Herweijer, C., Gordon, A.L., Kushnir, Y., Cook, E., 2007a. Blueprints for Medieval hydroclimate. Quaternary Science Reviews 26 (19-21), 2322-2336.

Seager, R., Ting, M.F., Held, I., Kushnir, Y., Lu, J., Vecchi, G., Huang, H.P., Harnik, N., Leetmaa, A., Lau, N.C., Li, C.H., Velez, J., Naik, N., 2007b. Model projections of an imminent transition to a more arid climate in southwestern North America. Science 316 (5828), 1181-1184.

Servant, M., Servant-Vildary, S., 1980. L'environnement quaternaire du bassin du Tchad. In: InWilliams, M.A.J., Faure, H. (Eds.), The Sahara and the Nile. Balkema, Rotterdam, pp. 133-162.

Stanhill, G., 1994. Changes in the rate of evaporation from the Dead Sea. International Journal of Climatology 14, 465-471.

Stein, M., 2001. The sedimentary and geochemical record of Neogene-Quaternary water bodies in the Dead Sea Basin - inferences for the regional paleoclimatic history. Journal of Paleolimnology 26 (3), 271-282.

Stein, M., Starinsky, A., Katz, A., Goldstein, S.L., Machlus, M., Schramm, A., 1997. Strontium isotopic, chemical, and sedimentological evidence for the evolution of Lake Lisan and the Dead Sea. Geochimica Et Cosmochimica Acta 61 (18) 3975-3992.

Stein, M., Torfstein, A., Gavrieli, I., Yechieli, Y., 2010. Abrupt aridities and salt deposition in the post-glacial Dead Sea and their North Atlantic connection. Quaternary Science Reviews 29 (3-4), 567-575.

Stine, S., 1990. Late Holocene fluctuations of Mono Lake, eastern California. Palaeogeography, Palaeoclimatology, Palaeoecology 78 (3-4), 333-381.

Sutton, R.T., Hodson, D.L.R., 2003. Influence of the ocean on North Atlantic climate variability 1871-1999. Journal of Climate 16 (20), 3296-3313.

Sutton, R.T., Hodson, D.L.R., 2007. Climate response to basin-scale warming and cooling of the North Atlantic Ocean. Journal of Climate 20 (5), 891-907.

Ting, M.F., Kushnir, Y., Seager, R., Li, C.H., 2009. Forced and Internal twentiethcentury SST trends in the North Atlantic. Journal of Climate 22 (6), 1469-1481.

Torfstein, A., Haase-Schramm, A., Waldmann, N., Kolodny, Y., Stein, M., 2009. U-series and oxygen isotope chronology of the mid-Pleistocene Lake Amora (Dead Sea basin). Geochimica Et Cosmochimica Acta 73 (9), 2603-2630.

Trigo, I.F., 2006. Climatology and interannual variability of storm-tracks in the EuroAtlantic sector: a comparison between ERA-40 and NCEP/NCAR reanalyses. Climate Dynamics 26 (2-3), 127-143.

Vellinga, M., Wood, R.A., 2002. Global climatic impacts of a collapse of the Atlantic thermohaline circulation. Climatic Change 54 (3), 251-267.

Verheyden, S., Nader, F.H., Cheng, H.J., Edwards, L.R., Swennen, R., 2008. Paleoclimate reconstruction in the Levant region from the geochemistry of a Holocene stalagmite from the Jeita cave, Lebanon. Quaternary Research 70 (3) $368-381$.

Waldmann, N., Starinsky, A., Stein, M., 2007. Primary carbonates and Ca-chloride brines as monitors of a paleo-hydrological regime in the Dead Sea basin. Quaternary Science Reviews 26 (17-18), 2219-2228.

Waldmann, N., Stein, M., Ariztegui, D., Starinsky, A., 2009. Stratigraphy, depositional environments and level reconstruction of the last interglacial Lake Samra in the Dead Sea basin. Quaternary Research 72 (1), 1-15.

Wallace, J.M., Gutzler, D.S., 1981. Teleconnections in the Geopotential Height field during the northern hemisphere winter. Monthly Weather Review 109 (4) 784-812.

Zhang, R., Delworth, T.L., 2005. Simulated tropical response to a substantial weakening of the Atlantic thermohaline circulation. Journal of Climate 18 (12) 1853-1860.

Zhang, R., Delworth, T.L., 2006. Impact of Atlantic multidecadal oscillations on India/Sahel rainfall and Atlantic hurricanes. Geophysical Research Letters 33 (17).

Ziv, B., Saaroni, H., Alpert, P., 2004. The factors governing the summer regime of the eastern Mediterranean. International Journal of Climatology 24 (14), 1859-1871.

Ziv, B., Dayan, U., Kushnir, Y., Roth, C., Enzel, Y., 2006. Regional and global atmospheric patterns governing rainfall in the southern Levant. International Journal of Climatology 26 (1), 55-73. 